\title{
New Insights into the Roles of Megalin/LRP2 and the Regulation of its Functional Expression
}

\author{
María-Paz Marzolo ${ }^{1,2, *}$ and Pamela Farfán ${ }^{1,2}$ \\ ' Laboratorio de Tráfico Intracelular y Señalización, Departamento de Biología Celular y Molecular, Facultad de Ciencias Biológicas. \\ 2 Millenium Nucleus in Regenerative Biology (MINREB). Pontificia Universidad Católica de Chile.
}

ABSTRACT

Since the discovery of the low-density lipoprotein receptor (LDLR) and its association with familial hypercholesterolemia in the early 1980 s, a family of structurally related proteins has been discovered that has apolipoprotein $\mathrm{E}$ as a common ligand, and the broad functions of its members have been described. LRP2, or megalin, is a member of the LDLR family and was initially called gp330. Megalin is an endocytic receptor expressed on the apical surface of several epithelial cells that internalizes a variety of ligands including nutrients, hormones and their carrier proteins, signaling molecules, morphogens, and extracellular matrix proteins. Once internalized, these ligands are directed to the lysosomal degradation pathway or transported by transcytosis from one side of the cell to the opposite membrane. The availability of megalin at the cell surface is controlled by several regulatory mechanisms, including the phosphorylation of its cytoplasmic domain by GSK3, the proteolysis of the extracellular domain at the cell surface (shedding), the subsequent intramembrane proteolysis of the transmembrane domain by the gamma-secretase complex, and exosome secretion. Based on the important roles of its ligands and its tissue expression pattern, megalin has been recognized as an important component of many pathological conditions, including diabetic nephropathy, Lowe syndrome, Dent disease, Alzheimer's disease (AD) and gallstone disease. In addition, the expression of megalin and some of its ligands in the central and peripheral nervous system suggests a role for this receptor in neural regeneration processes. Despite its obvious importance, the regulation of megalin expression is poorly understood. In this review, we describe the functions of megalin and its association with certain pathological conditions as well as the current understanding of the mechanisms that underlie the control of megalin expression.

Key words: Alzheimer's Disease, cubilin, diabetic nephropathy, FXR, gallstone disease, GSK3, Lowe syndrome, megalin, PPAR, RAP, regeneration.

\section{MEGALIN STRUCTURE AND INTRACELLULAR TRAFFICKING}

Megalin/LRP2, as its name indicates, is a giant membrane glycoprotein of $600 \mathrm{kDa}$ that belongs to the low-density lipoprotein receptor (LDLR) protein family. The members of this family are type I membrane proteins that act mainly at the cell surface, where they efficiently bind and internalize several physiologically relevant molecules, such as the cholesterol carrier apolipoprotein $\mathrm{E}$, which is a common ligand recognized by all LDLR receptors (Willnow et al., 1992; Hussain, 2001) (Table I). Megalin is composed of a large extracellular domain consisting of four cysteine-rich complement-type ligand binding repeats, responsible for ligand binding, that binds to the chaperone RAP (receptor associated protein) for its folding in the endoplasmic reticulum (ER) (Bu and Marzolo, 2000). The repeats are separated from each other by $\beta$-propeller domains (Saito et al., 1994), structured by repeats of YWTD flanked by EGF-like modules, that are generally important for the proper receptor folding in this family of proteins (Culi et al., 2004; Lighthouse et al., 2010) as well as for the dissociation of their ligands in the acidic endosomal compartment (Jeon et al., 2001) (Fig. 1). In addition, megalin contains one transmembrane domain that targets it to membrane domains rich in cholesterol and glycosphingolipids (Marzolo et al., 2003) and is also a substrate for the gamma-secretase complex (Zou Z et al., 2004; Biemesderfer, 2006).

Next to the transmembrane domain, human megalin has a cytoplasmic domain of 209 amino acid residues that contains several motifs that regulate receptor trafficking and function
(Fig. 2A). Among these are three NPXY motifs that have been linked to LDLR and LRP1 internalization mediated by clathrin, recycling from the endosomal compartment to the plasma membrane and basolateral distribution (Bansal and Gierasch, 1991; Matter et al., 1992; Li et al., 2001; van Kerkhof et al., 2005; Donoso et al., 2009). However, the roles of these motifs have not been clearly defined for megalin/LRP2. In fact, there are evidences linking megalin endocytosis to nonclathrin mediated pathways involving trafficking proteins such as the small GTPase Arf6 (Wolff et al., 2008) and caveolin 1 (Bento-Abreu et al., 2009). Two cytoplasmic proline-rich sequences and a PDZ-binding motif have been implicated in the direct and indirect interaction of megalin with cytoskeletal and cytosolic scaffold and signaling proteins, such as GIPC/ synectin, megalin-binding protein, ANKRA, myosin VI, SKIP, Disabled 2 (Dab2) and APPL1 (Rader et al., 2000; Patrie et al., 2001; Larsson et al., 2003; Petersen et al., 2003; Naccache et al., 2006; Erdmann et al., 2007). An unusual feature of megalin among the LRP family of receptors (with the exception of LRP5 and 6 , which participate in Wnt $/ \beta$ catenin signaling (Zeng et al., 2005)), is that it is constitutively phosphorylated by GSK3 at a PPPSP motif, contained in a distal proline-rich motif of the cytoplasmic tail (Yuseff et al., 2007). This PPPSP motif is the most significant in terms of basal phosphorylation of the receptor, despite the presence of several other consensus phosphorylation sites for PKC, CK-II and PKA (Fig. 2A) and its function is related to the control of megalin recycling from the endosomes (Yuseff et al., 2007) (see section 4.3). Both the PPPSP motif and the PDZ-binding motif are very well conserved in megalin sequences from different species (Fig. 2B). 


\begin{tabular}{|cl|}
\hline 0 & CUB domain \\
0 & EGF-type repeat \\
0 & Complement type repeat \\
88 & YWTD-region ( $\beta$-propeller) \\
80 & NPXY motif \\
0 & Transmembrane domain \\
\hline
\end{tabular}

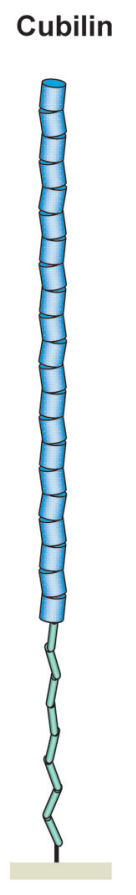

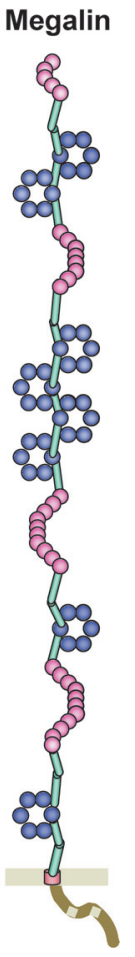

Figure 1. Schematic representation of megalin and its coreceptor cubilin: Megalin shares common structural motifs with other members of the LDLR family, including ligand-binding repeats, epidermal growth factor (EGF) repeats, YWTD spacer domains, a single transmembrane domain and a short cytoplasmic domain containing conserved endocytic motifs. Cubilin is a peripheral membrane protein with 27 cub domains and a sequence with amphipathic helical characteristics located in the amino-terminal region that has been implicated in cubilin plasma membrane anchoring/association. Cubilin requires megalin for its internalization.
The expression of megalin is principally restricted to epithelial cells, specifically at the apical surface (Cui et al., 1996; Morales et al., 1996; Willnow et al., 1996; Nielsen et al., 1998; Zheng et al., 1998; Hermo et al., 1999; Mizuta et al., 1999). Interestingly, despite the presence of some putative basolateral sorting motifs in the cytoplasmic domain of megalin, its apical localization depends mainly on sorting information present in this domain of the receptor because its addition to a reporter protein that lacks sorting information drives trafficking of the reporter to the apical surface of polarized epithelial cells (Marzolo et al., 2003) (Fig. 3). Under some specific ligandtriggered conditions, the apical localization of megalin can be transiently modified by transcytosis, a trafficking pathway that drives the internalized receptor to the opposite cell surface instead of allowing the receptor to recycle to the origin membrane domain. Megalin transcytosis has been detected in different epithelial cells and tissues, and is involved in the transport of internalized ligands such as thyroglobulin (Marino et al., 2000), Retinol Binding Protein (RBP) (Marino et al., 2001), leptin (Dietrich et al., 2008), sonic hedgehog (Shh) (Morales et al., 2006) and albumin (Russo et al., 2007) to the opposite plasma membrane and their release to the extracellular environment without degradation.

\section{TISSUE DISTRIBUTION AND FUNCTIONS OF MEGALIN}

Megalin is expressed in some tissues with cubilin (Fig.1), a peripheral membrane protein that requires megalin for its internalization. During mammalian development, megalin and cubilin are already expressed at the 8-cell stage at the time of segregation between the inner cell mass and the throphectoderm (Assemat et al., 2005a). After implantation, megalin and cubilin are expressed in the visceral endoderm (Kalantri et al, 2001) that becomes the visceral yolk sac, which in rodents has a central role in the nutrition of the embryo.

A

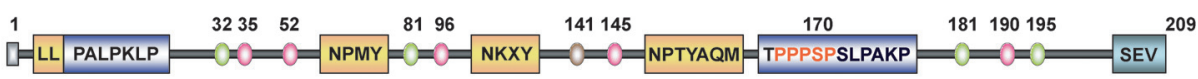

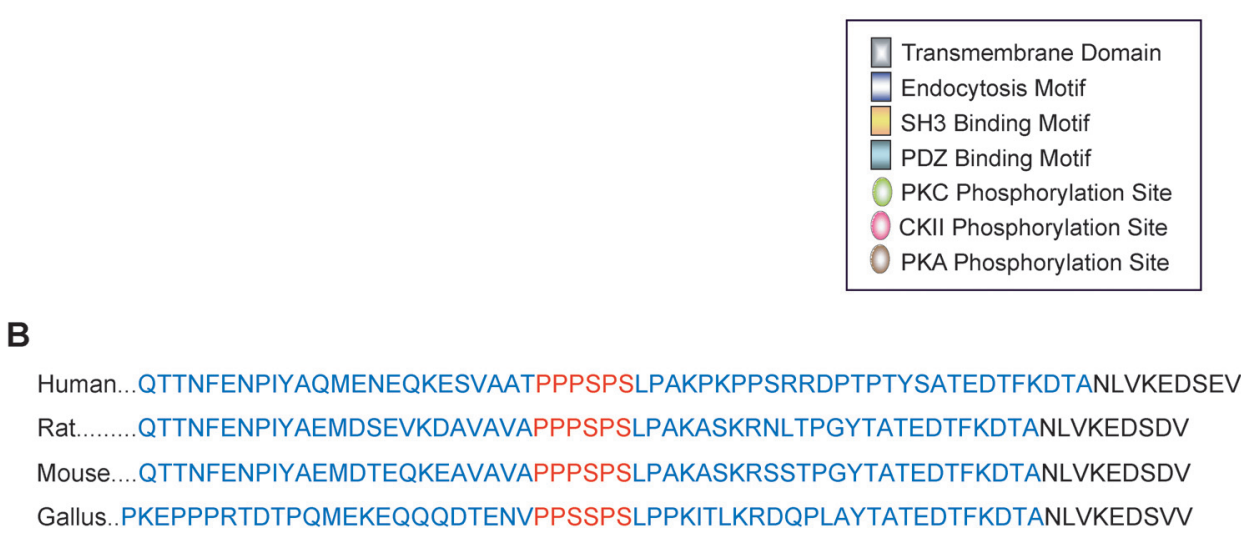

Figure 2. Characteristics of the megalin cytoplasmic domain that determine its trafficking and phosphorylation: a) The 209 amino acid residue cytoplasmic domain of megalin has several putative internalization motifs, including one dileucine and three NPxY motifs. In addition, it contains two proline-rich sequences, one PDZ terminal motif, several putative protein kinase C and casein kinase II phosphorylation motifs as well as one protein kinase A phosphorylation motif. Under basal conditions, these motifs contribute little to the phosphorylation of the megalin cytoplasmic domain. However, within the distal, proline-rich motif there is a PPPSP motif that is responsible for megalin phosphorylation by GSK3 $\beta$ (Yuseff et al., 2007). b) The PPPSP motif (red) is highly conserved in the sequences of megalin cytoplasmic domains from different species, suggesting that the regulation of megalin trafficking and surface expression by GSK3-mediated phosphorylation is a conserved mechanism. 
This would allow the capture of nutrients, as apoAI-bearing lipoproteins, for the developing foetus (Assemat et al., 2005a).

\subsection{Megalin in the central nervous system}

Megalin is expressed early in the development of the neural tube, and it is present in the floor plate (McCarthy et al., 2002)). In the mice neuroepithelium megalin is found at E9.5 (Willnow et al., 1996). The receptor has a role in the formation of brain structures (Willnow et al., 1996; Spoelgen et al., 2005; Wicher et al., 2005). In the adult, megalin expression is restricted in the central nervous system (CNS) to the choroid plexus (Chun et al., 1999; Carro et al., 2005), the ependymal cells of the lateral ventricles (Gajera et al., 2010) and in spinal cord (Wicher et al., 2006). Megalin expression has been reported in the sensory organs, such as
A

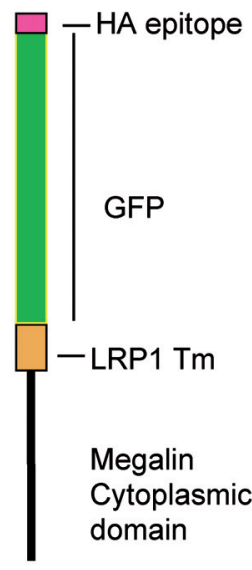

GFP-MegT

C

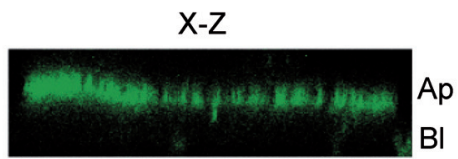

E

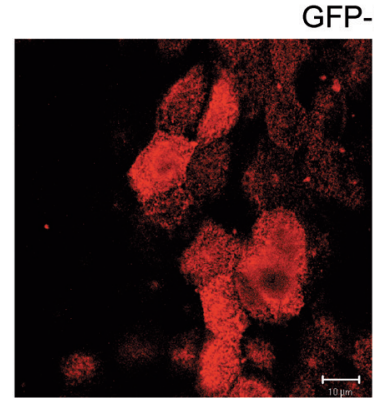

Anti-HA (apical plane)

B

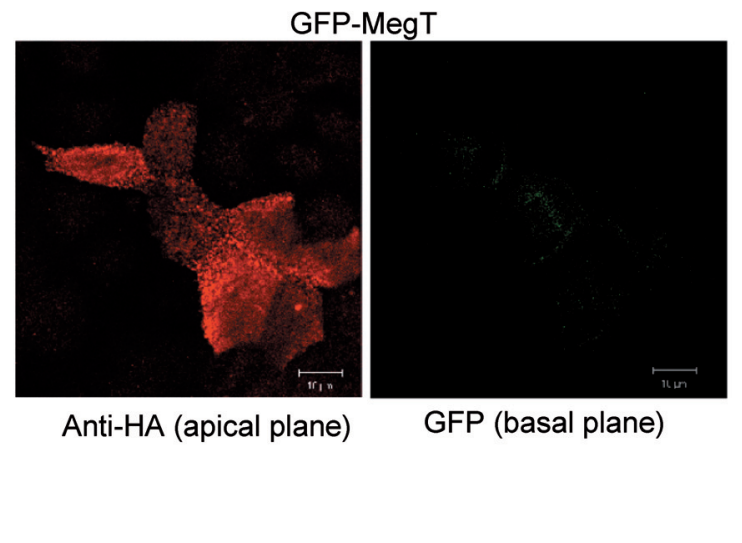

D

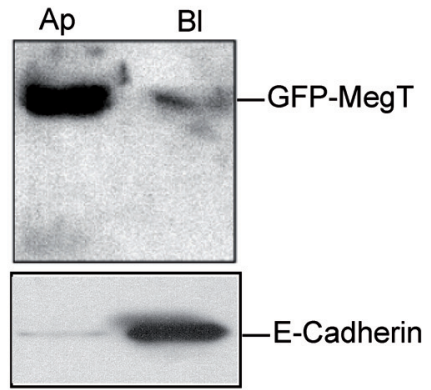

$\mathbf{F}$
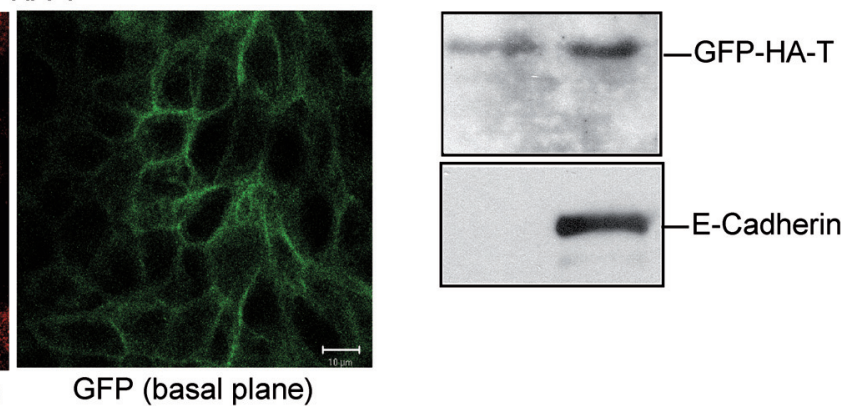

Figure 3. The cytoplasmic domain of megalin contains the information responsible for targeting the protein to the apical surface of polarized epithelial cells (Marzolo et al., 2003). a) Scheme of the chimeric protein consisting of green fluorescent protein (GFP) with an amino-terminal HA epitope, the transmembrane segment of the basolateral receptor LRP1 and the cytoplasmic domain of megalin (GFPMegT). b) Confocal microscopy of non-permeabilized MDCK cells grown on filters expressing GFP-MegT, showing that it is expressed at the apical surface (detected with an anti-HA antibody), whereas at the basal plane, there is no basolateral GFP signal. c) The X-Z plane shows GFP staining at the apical surface. d) Domain-specific cell surface biotinylation of MDCK cells expressing GFP-MegT shows the apical distribution of the protein, detected with anti-megalin cytoplasmic tail antibody (Marzolo et al., 2003). The monolayer is correctly polarized as the endogenous protein E-Cadherin is localized basolaterally. As controls, the non-polarized distribution of the chimeric protein, GFPHA-T, containing the cytoplasmic domain of haemaglutinin (with no sorting information) is shown by confocal microscopy (e) and cell surface biotinylation (f). 
the inner ear (Mizuta et al., 1999; Konig et al., 2008) and the eye (Lundgren et al., 1997; Assemat et al., 2005a; Fisher and Howie, 2006). The presence of megalin has been also found in non-epithelial cells, such as a subpopulation of neural progenitors in the embryonic mouse spinal cord (Wicher et al., 2005), oligodendrocytes of the mouse spinal cord (Wicher et al., 2006), retinal ganglion cells (Fitzgerald et al., 2007) and cerebellar granule neurons (Ambjorn et al., 2008). To uncover the physiological functions of megalin, complete knock-out (KO) mice (Willnow et al., 1996) and several conditional KOs (Leheste et al., 2003; Rubera et al., 2004; Spoelgen et al., 2005; Gajera et al., 2010) have been generated. Mice completely deficient in megalin have a low survival rate $(1 / 50)$ and die immediately after birth from respiratory insufficiency (Willnow et al., 1996). These animals exhibit a set of brain malformations known as holoprosencephaly that include forebrain fusion, a common ventricular system and lack of the olfactory bulb (Willnow et al., 1996). Conditional KO mice that lack megalin expression only in the brain show that this receptor has an important role in the development of the ventral telencephalon, which is due to its function as a receptor for signaling proteins and morphogens such as Shh and Bone Morphogenetic Protein 4 (BMP4) (McCarthy et al., 2002; Spoelgen et al., 2005). Megalin also controls BMP4 levels and activity in adult brain neurogenesis (Gajera et al., 2010).

Megalin expression in CNS and the role of several of its ligands in neuronal survival and regeneration have implicated this receptor as a likely mediator of CNS regeneration. Megalin is the receptor for metallothionein (Klassen et al., 2004; Wolff et al., 2006; Fitzgerald et al., 2007), which is neuroprotective and important for regeneration processes (Fitzgerald et al., 2007; Ambjorn et al., 2008; Chung et al., 2008; Pedersen et al., 2009). Cystatin C (Kaseda et al., 2007), clusterin/ApoJ (Bonnard et al., 1997; Min et al., 2003) and apolipoprotein E (White et al., 2001) are other megalin ligands with regenerative and neuroprotective functions in the CNS, but their requirement for megalin as a receptor in regeneration has not been demonstrated. Where and how megalin acts in the adult CNS is still open to debate and requires further study.

Recently megalin has been implicated in the regeneration of the peripheral nervous system because the receptor is responsible for the internalization of transthyretin (Fleming et al., 2009a), a plasmatic and cerebrospinal fluid carrier protein for thyroxine (T4) and vitamin A (Monaco, 2000; Palha, 2002; Fleming et al., 2009b).

\subsection{Role of megalin in the kidney and other organs}

Megalin is also present in the kidney, lung and thyroid (Willnow et al., 1996; Lundgren et al., 1997; Marino et al., 1999), epydidimis (Hermo et al., 1999), mammary gland (Lundgren et al., 1997; Rowling et al., 2006) and gallbladder (Erranz et al., 2004; Tsaroucha et al., 2008).

In the kidney the receptor has a central and relevant role mediating the recapture of filtered molecules at the level of the proximal tubule (PT) (Leheste et al., 1999; Leheste et al., 2003). Mice that do not express megalin have low molecular weight (LMW) proteinuria, and lose lysosomal proteins in the urine, indicating a role for megalin in the recapture of these enzymes as well as in the biogenesis of lysosomes of the PT cells (Nielsen et al., 2007). Megalin KO mice have important ultrastructural changes in the endosomal compartments of PT epithelial cells, including the absence of apical dense tubules, which correspond to the apical recycling compartment, and other endocytic structures, such as clathrin-coated pits and vesicles (Leheste et al., 1999). Recently, a new function has been discovered for megalin using a mouse strain (line 267) carrying a nonsense mutation in the extracellular domain of the receptor. These mice lose selenium in the urine and also have reduced selenium in brain; on a low-selenium diet, these mice exhibit movement coordination problems (Chiu-Ugalde et al., 2010). This phenotype is due to the role of megalin as a receptor of selenoprotein (Olson et al., 2008).

Other molecules that are bound and internalized by megalin in different tissues include the apolipoproteins apoE and clusterin/apoJ (Kounnas et al., 1995; Morales et al., 1996; Zlokovic et al., 1996; Hammad et al., 2000; Christoffersen et al., 2006), signaling molecules such as angiotensin II and 1-7 (Gonzalez-Villalobos et al., 2005; Gonzalez-Villalobos et al., 2006), leptin (Hama et al., 2004; Dietrich et al., 2008), and insulin (Orlando et al., 1998), albumin (Cui et al., 1996) as well as complexes of vitamins, such as D, B12 and A, with their corresponding vitamin-binding proteins (Christensen and Willnow, 1999) and steroid hormones in complex with sex hormone-binding globulin (Table I). Some of these ligands are also recognized by cubilin (Table II). Megalin thus plays a key role in the internalization and activation of molecules such as vitamin D and vitamin D-binding protein (DBP), whose activation from the $25-\mathrm{OH}$ form to the active $1,25-\mathrm{OH}$ form occurs predominantly in the kidney. Interestingly, the systemic role of megalin in calcium homeostasis and bone metabolism can be almost completely recapitulated in a mouse model with conditional inactivation of the megalin gene in the kidney (Leheste et al., 2003). Megalin renal functions and its ligands explain why megalin $\mathrm{KO}$ mice suffer from extensive proteinuria, low bone density and rickets (Nykjaer et al., 1999). In addition to the kidney, megalin-mediated vitamin D activation also occurs in other tissues, such as the mammary glands (Rowling et al., 2006; Chlon et al., 2008), bone (van Driel et al., 2006) and the liver, specifically in stellate cells (Gressner et al., 2008). Furthermore, megalin may have an antifibrotic role as a receptor for connective tissue growth factor (CTGF) (Gerritsen et al., 2010), which plays a key role in fibrosis in several organs, including the kidney and gallblader. Megalin KO mice lose CTGF in the urine, and the blockage of tubular reabsorption in human healthy volunteers induces an increase of urinary CTGF excretion (Gerritsen et al., 2010).

\section{IMPAIRMENT OF MEGALIN EXPRESSION AND FUNCTION IN DISEASE}

Megalin expression, trafficking and/or its ligands are likely involved in some disease conditions that compromise the functioning of organs such as kidney, brain, mammary gland, thyroid and gallbladder. In this context it is important to understand the mechanisms that regulate megalin expression and availability. 
TABLE I

Megalin Ligands

\begin{tabular}{|c|c|}
\hline Ligands & Reference \\
\hline Albumin & (Cui et al., 1996) \\
\hline Aminoglycosides & (Moestrup et al., 1995) \\
\hline$\alpha$ Amylase & (Birn et al ., 2000a) \\
\hline Angiotensin II & (Gonzalez-Villalobos et al., 2005) \\
\hline Angiotensin 1-7 & (Gonzalez-Villalobos et al., 2006) \\
\hline Apolipoprotein B & (Stefansson et al., 1995b) \\
\hline Apolipoprotein E & (Willnow et al., 1992) \\
\hline Apolipoprotein $\mathrm{H}$ & (Moestrup et al., 1998) \\
\hline Apolipoprotein J/Clusterin & (Kounnas et al., 1995) \\
\hline Apolipoprotein M & (Faber et al ., 2006) \\
\hline Aprotinin & (Moestrup et al., 1995) \\
\hline Bone morphogenetic protein 4 & (Spoelgen et al., 2005) \\
\hline $\mathrm{Ca} 2+$ & (Christensen et al., 1992) \\
\hline Cathepsin b & (Nielsen et al., 2007) \\
\hline Coagulation factor VIII & (Ananyeva et al., 2008) \\
\hline Connective tissue growth factor (CTGF) & (Gerritsen et al., 2010) \\
\hline Cytochrome C & (Orlando et al ., 1998) \\
\hline Cystatin C & (Kaseda et al., 2007) \\
\hline Epidermal growth factor & (Orlando et al ., 1998) \\
\hline Folate binding protein & (Birn et al., 2005) \\
\hline$\alpha$ Galactosidase A & (Christensen et al., 2007) \\
\hline Gelsolin & (Vargas et al., 2010a) \\
\hline Hemoglobin & (Gburek et al., 2002) \\
\hline Insulin & (Orlando et al ., 1998) \\
\hline Insulin-like growth factor I (IGF-I) & (Bolos et al., 2010) \\
\hline Lactoferrin & (Willnow et al., 1992) \\
\hline Leptin & (Hama et al., 2004; Dietrich et al., 2008) \\
\hline Lipoprotein lipase & (Kounnas et al., 1993) \\
\hline Liver type fatty acid binding protein & (Oyama et al., 2005) \\
\hline $\mathrm{Lp}(\mathrm{a})$ & (Niemeier et al., 1999) \\
\hline Lysozyme & (Orlando et al ., 1998) \\
\hline Metallothionein & (Klassen et al., 2004) \\
\hline$\beta 1$ Microglobulin & (Leheste et al., 1999) \\
\hline$\alpha_{2}$ Microglobulin & (Orlando et al ., 1998) \\
\hline Myoglobin & (Gburek et al., 2003) \\
\hline Neutrophil gelatinase associated lipocalin & (Hvidberg et al., 2005) \\
\hline Odorant binding protein & (Leheste et al., 1999) \\
\hline Parathyroid hormone & (Hilpert et al., 1999) \\
\hline Pancreatitis associated protein 1 & (Leheste et al., 1999) \\
\hline Plasminogen & (Kanalas and Makker, 1991) \\
\hline Plasminogen activator inhibitor type 1 & (Stefansson et al., 1995a) \\
\hline Plasminogen activator inhibitor type 1 urokinase & (Moestrup et al., 1993) \\
\hline Plasminogen activator inhibitor type 1 tissue plasminogen activator & (Moestrup et al., 1993) \\
\hline Polymyxin B & (Moestrup et al., 1995) \\
\hline Prolactin & (Orlando et al ., 1998) \\
\hline Pro urokinase & (Stefansson et al., 1995a) \\
\hline Recombinant activated factor VIIa (rFVIIa) & (Seested et al., 2010) \\
\hline Retinol binding protein & (Christensen et al., 1999) \\
\hline Seleno protein $\mathrm{P}$ & (Olson et al., 2008) \\
\hline Seminal vesicle secretory protein II & (Ranganathan et al., 1999) \\
\hline Sex hormone binding globulin & (Hammes et al., 2005) \\
\hline Sonic hedgehog protein & (McCarthy et al., 2002) \\
\hline Thyroglobulin & (Zheng et al., 1998) \\
\hline Transcobalamin vitamin B12 & (Moestrup et al., 1996) \\
\hline Transthyretin & (Sousa et al., 2000) \\
\hline Trichosantin & (Chan et al., 2000) \\
\hline Vitamin D binding protein & (Nykjaer et al., 1999) \\
\hline
\end{tabular}


TABLE II

Cubilin Ligands

\begin{tabular}{|ll|}
\hline Ligands & Reference \\
\hline Albumin & (Birn et al., 2000b) \\
Aminoglycosides & (Tauris et al., 2009) \\
Apolipoprotein Al & (Hammad et al., 1999; Kozyraki et al., 1999) \\
Apolipoprotein AII & (Dugue-Pujol et al., 2007) \\
Clara cell secretory protein & (Burmeister et al., 2001) \\
Hemoglobin & (Gburek et al., 2002) \\
High density lipoprotein & (Hammad et al., 1999; Kozyraki et al., 1999) \\
Inmunoglobulin light chains & (Batuman et al., 1998) \\
Intrinsic factor vitamin B12 & (Birn et al., 1997) \\
Myoglobin & (Gurek et al., 2003) \\
Recombinant activated factor VIIa (rFVIIa) & (Seested et al., 2010) \\
Transferrin & (Kozyraki et al., 2001) \\
Vitamin D binding protein & (Nykjaer et al., 2001) \\
\hline
\end{tabular}

\subsection{Mutations of megalin gene associated with human diseases}

Two related, extremely rare conditions directly associated with megalin/LRP2 mutation are Donnai-Barrow syndrome and facio-oculo-acoustico-renal (FOAR) syndrome (Kantarci et al., 2007; Kantarci et al., 2008; Pober et al., 2009). Both conditions are caused by mutations in $\operatorname{lrp} 2$ and are characterized by agenesis of the corpus callosum, developmental delay, proteinuria, hearing loss and ocular abnormalities. These defects highlight the importance of megalin during development in organs such as brain, eye, ear and kidney.

\subsection{Kidney disease and the role of megalin}

Megalin ligands such as albumin, insulin, leptin, PTH and angiotensin II have been implicated in pathological conditions, including diabetes, hypertension and obesity (Mezzano et al., 2003; Tojo et al., 2003; Vio and Jeanneret, 2003; Saito et al., 2005; Zhang et al., 2005; Wolf and Ziyadeh, 2006; Pollock and Poronnik, 2007), many of which affect renal function. Similarly, megalin-interacting proteins may be involved in disease pathology. For example, the activity of $\mathrm{Na}(+) / \mathrm{H}(+)$ exchanger isoform 3 (NHE3) is negatively modulated by megalin association (Biemesderfer et al., 1999; Biemesderfer et al., 2001), and its activity is increased in models of diabetes mellitus, which partially explains the $\mathrm{Na}(+)$ retention observed in diabetic patients with kidney disease (Hryciw et al., 2004). As a consequence of these disease-related conditions, megalin expression can be severely compromised, accounting for some common features observed in them, specifically the low molecular weight proteinuria and albuminuria. The mechanisms underlying megalin downregulation under these conditions are not known, but they could be related to the activation of the renin-angiotensin system (Tojo et al., 2003), increased TGF $\beta$ signaling and increased albumin overload in the lumen of the PT (see also section 4.1).

The cell surface expression of megalin is altered, possibly due to membrane trafficking defects, in two genetic diseases linked to the X-chromosome, Lowe syndrome and Dent disease. In both conditions, protein and salt resorption are affected in kidney proximal tubular cells, ultimately leading to progressive renal failure in these patients (Bockenhauer et al., 2008; Cho et al., 2008). Lowe syndrome, also known as Oculo-cerebro-renal Lowe syndrome, is characterized by congenital cataracts, mental retardation and renal Fanconi syndrome. The latter consists of LMW proteinuria and proximal tubular acidosis. The gene responsible for the disease is OCRL, a phosphatidylinositol 4,5-bisphosphate (PIP(2))-5-phosphatase located on the $X$ chromosome. Dent Disease is also a rare $\mathrm{X}$-linked, recessively inherited proximal renal tubular disorder characterized by LMW proteinuria, hypercalciuria and nephrocalcinosis/nephrolithiasis, but only renal function is affected in these patients. Dent- 1 disease is mainly caused by mutations in CLCN5, the gene encoding the chloride channel ClC-5 (Marshansky et al., 2002), and Dent-2 is caused by mutations in OCRL (Hoopes et al., 2005; Utsch et al., 2006; Sekine et al., 2007; Cho et al., 2008). Reduced excretion of megalin normally found in the urine has been reported in both Lowe syndrome and Dent disease (Norden et al., 2002; Watanabe, 2004), suggesting that megalin expression at the PT cells apical surface could be impaired in these diseases. The absence of $\mathrm{ClC}-5$ in some patients is related to a significant reduction in megalin expression in PT cells. Some the characteristics of these diseases are found in megalin $\mathrm{KO}$ mice, such as LMW proteinuria, as well as the loss of retinol binding protein (RBP), DBP and 25-hydroxy $(\mathrm{OH})$ vitamin $\mathrm{D}$, explaining the rickets. In addition, mouse models for Dent disease have altered expression of megalin in the PT cells (Guggino, 2007). However, it is currently unclear how mutations in the OCRL and $\mathrm{ClC}-5$ genes may affect receptor expression and/or trafficking. It has been suggested that the lack of $\mathrm{ClC}-5$ activity could be related to a failure in endosome acidification and therefore impair megalin recycling to the plasma membrane (Marshansky et al., 2002; Hryciw et al., 2006). OCRL was shown to be able to bind the adaptor protein APPL1, which interacts with megalin cytoplasmic domain (Erdmann et al., 2007). Some effects of the absence of OCRL on endosome dysfunctions and megalin expression at the cell surface in Lowe syndrome have been recently proposed (see 
section 4.2). A mouse model for Lowe Syndrome was recently developed (Bothwell et al., 2010) and will help to elucidate how OCRL affects megalin in vivo.

\subsection{Role of megalin in cholesterol homeostasis}

As a lipoprotein receptor, megalin plays a relevant role in cholesterol transport. This is particularly clear during development (Willnow et al., 1996), functioning along with its coreceptor cubilin (Assemat et al., 2005b). In addition to apoE, megalin is the receptor for apoJ/clusterin, which is associated with HDL particles (Kounnas et al., 1995; Calero et al., 1999), and also for $\mathrm{Lp}(\mathrm{a})$, an atherogenic particle (Niemeier et al., 1999; Willnow, 1999). Apolipoprotein $\mathrm{M}$ is a lipocalin with antiatherogenic properties that is present in pre- $\beta$-HDL particles, chylomicrons, VLDLs and LDLs secreted by the liver and the kidney that use megalin as a receptor (Dahlback and Nielsen, 2006; Faber et al., 2006; Dahlback and Nielsen, 2009). In addition to apoM, megalin with its coreceptor cubilin, internalizes apoA-I and apoA-II, structural components of HDLs (Hammad et al., 2000; Dugue-Pujol et al., 2007). Taken together, these data indicate that megalin contributes to the regulation of HDL metabolism. In fact, plasma cholesterol levels and LDL cholesterol have been associated with genetic variations in the megalin gene in the Japanese population (Mii et al., 2007), further suggesting that this receptor has a systemic function in cholesterol homeostasis.

\subsection{Megalin in Gallstone Disease}

The presence of megalin and cubilin in gallbladder epithelial cells (Fig. 4A) (Erranz et al., 2004), but not in liver cells, also suggests the participation of these receptors in biliary cholesterol management. The bile is mainly composed of water, free cholesterol, phospholipids and bile salts secreted by the hepatocytes. In addition, bile contains many proteins that are megalin and/or cubilin ligands, including albumin and apolipoproteins that can act as factors that promote or inhibit gallstone formation. Gallbladder epithelial cells express NHE3 at the apical membrane (Colombani et al., 1996; Silviani et al., 1996; Narins et al., 2004), which could be regulated by megalin as it is in PT cells (Biemesderfer et al., 1999; Biemesderfer et al., 2001). In this way, megalin could regulate bile $\mathrm{pH}$, which is a factor to consider in lithogenicity and gallstone formation. The $\operatorname{lrp} 2$ gene is present in the Lith1 locus of mice, suggesting its relationship to cholesterol gallstone susceptibility (Bouchard et al., 1999). Gallstone disease is a multifactorial condition of the gallbladder, which involves genetic, sex, age and environmental variables (Lammert and Miquel, 2008). A study of a small number of gallstone patients in the Greek population found that both megalin and cubilin were downregulated in gallstone patients at the mRNA and protein levels (Tsaroucha et al., 2008). On the other hand, we have found that gallstone-susceptible mice fed a cholesterolrich lithogenic diet showed a reduction in megalin mRNA expression (Fig. 4B) even before they developed cholesterol crystals or gallstones. Our data also indicate that megalin protein expression is not regulated by cholesterol but is under the control of bile acids (Erranz et al., 2004). This regulatory role of bile acids, have prompt us to test the role of the bile acid receptor FXR in megalin expression (see section 4.1). How the presence of megalin in the gallbladder affects the susceptibility to gallstone development, is a subject of our ongoing studies. Considering the roles of megalin in other tissues and the factors that control bile lithogenicity, megalin could control bile composition by participating in the transport of cholesterol, the regulation of protein bile protein content and/or the activity of proteins such as NHE3. In addition, in gallstone disease there is fibrosis of the gallbladder, induced by the production of TGF $\beta$ and the megalin ligand CTGF (Koniniger et al., 2005). A reduction of megalin protein could further promote the fibrotic environment in the gallbladder, increasing the organ dysmotility.

\subsection{Megalin in Alzheimer's Disease}

In the brain, the presence of megalin has been implicated in neurodegenerative conditions such as Alzheimer's disease (AD), especially in terms of its protective role in the choroid plexus. Megalin facilitates the clearance of the A $\beta$ peptide that is produced by amyloidogenic processing of the amyloid precursor protein (APP), which can form complexes with different megalin ligands such as clusterin/apoJ (Zlokovic, 1996; Zlokovic et al., 1996; Hammad et al., 1997; Nuutinen et al., 2009) and apoE (Zlokovic, 1996; Zlokovic et al., 1996; Bell et al., 2007). In addition to these ligands, a role for the $A \beta$ binding protein gelsolin (Ji et al., 2010; Li et al., 2010), a protein that is produced in the epithelial cells of the choroid plexus (Vargas et al., 2010a), was recently demonstrated. Gelsolin has neuroprotective functions in controlling the $A \beta$-induced production of $\mathrm{NO}$ and apoptosis as well as cytoskeletal disruptions in the epithelial cells of the cerebrospinal fluid barrier (Vargas et al., 2010a). The neuroprotective roles of gelsolin were also demonstrated in vivo in an AD mouse model and probably require megalin as a receptor (Antequera et al., 2009). Recently, a genetic study found a G/A polymorphism in the megalin promoter that reduced the expression of megalin by $20 \%$, whose association with $\mathrm{AD}$ is dependent on the apoE genotype (Vargas et al., 2010b). In addition to A $\beta$ peptide, the protective role of megalin in $\mathrm{AD}$ and neurodegenerative conditions is suggested by its role in the incorporation of the neurotrophic factor IGF-I from the serum to the brain through a mechanism that is negatively regulated by GSK3-mediated phosphorylation of the megalin cytoplasmic domain (see section 4) (Bolos et al., 2010). As mentioned, megalin also regulates the transport of leptin in the choroid plexus by transcytosis (Dietrich et al., 2008). Leptin levels have been related to a decrease in the activity of $\beta$-secretase or BACE (Marwarha et al., 2010), the limiting step in the formation of $A \beta$ from APP. Decreases of megalin expression with age and in AD patients (Odera et al., 2007; Dietrich et al., 2008) would thus reduce the protective effects of the receptor on brain function.

\section{MECHANISMS REGULATING MEGALIN $\mu$ RNA AND PROTEIN LEVELS AND CELL SURFACE EXPRESSION}

Despite current knowledge regarding the different roles of megalin during development and in adult tissues, very little is known about the mechanisms that control its expression and availability at the cell surface. There are several possible mechanisms that could control megalin abundance, including the regulation of its mRNA levels, protein synthesis and protein half-life as well as trafficking of megalin to the cell surface. 
A

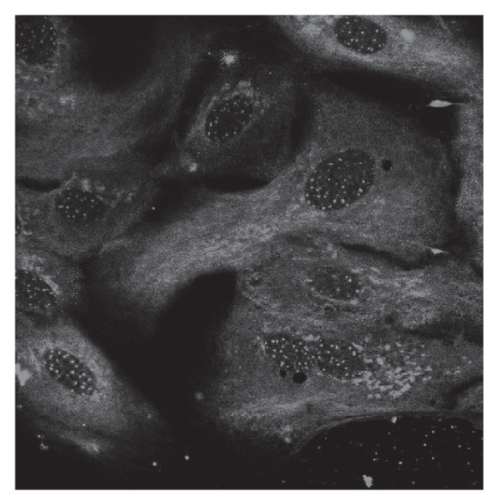

C

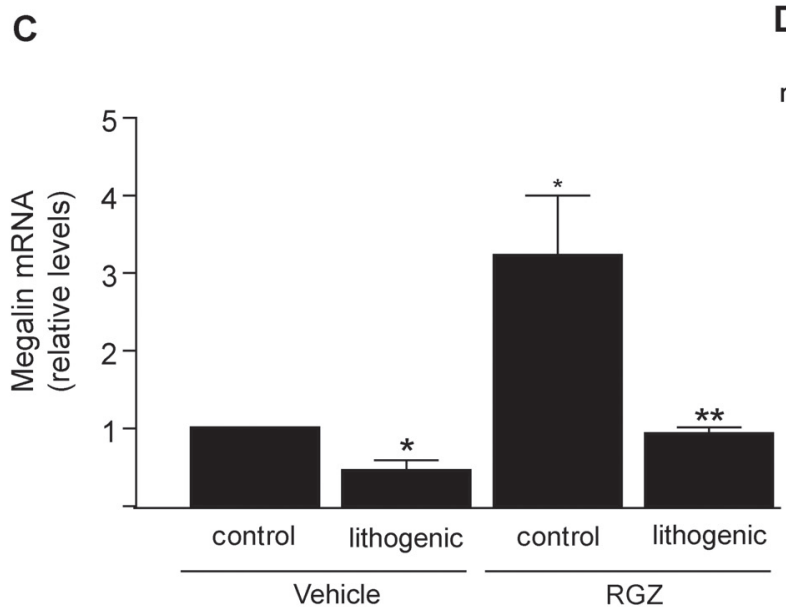

B
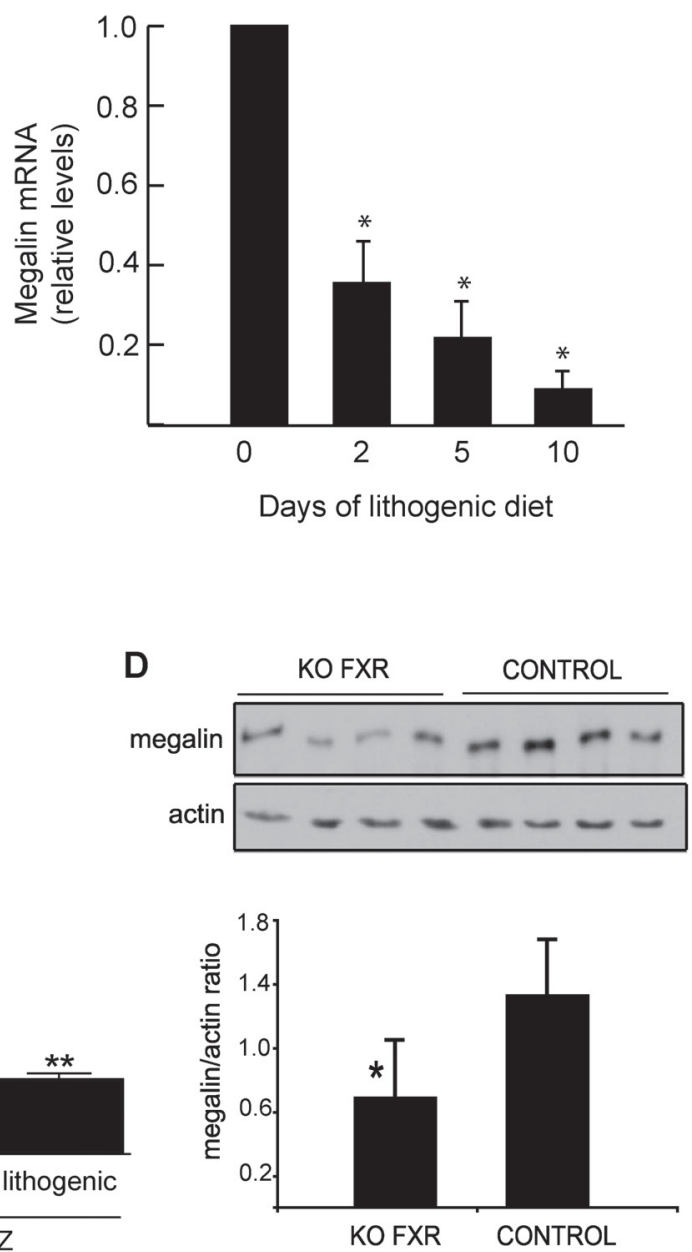

Figure 4. Megalin expression is regulated by a lithogenic diet and the nuclear receptors PPAR $\gamma$ and FXR. a) The presence of megalin in gallbladder epithelial cells in primary culture, detected by an antibody against the cytoplasmic domain of the receptor with confocal microscopy. b) In 8-week-old mice fed a lithogenic diet, the expression of gallbladder megalin mRNA determined by qPCR (relative to GAPDH as a housekeeping gene) was significantly downregulated from the second day ( $n=4$ mice per group). Values are average \pm SD. c) Pretreatment of mice with the PPAR $\gamma$ agonist rosiglitazone $(20 \mathrm{mg} / \mathrm{kg} /$ day) for two days, followed by either control diet or lithogenic diet for 10 days in the presence of rosiglitazone or vehicle, shows that rosiglitazone treatment significantly increased megalin mRNA expression, determined by GPCR, in control animals. In mice fed the lithogenic diet for 10 days, the PPAR $\gamma$ agonist rescued the reduction in megalin mRNA ( $n=4$ mice per group). Values are average $\pm \mathrm{SD}, * P<0.05$ vs. megalin control, $* * P<0.05$ vs. megalin under lithogenic diet. $d$ ) Detection of megalin protein by western blot from mouse kidney cortex. The expression of megalin in kidney of mice null for the nuclear receptor FXR is significantly reduced compared to the controls. ${ }^{*} P<0.05$

\subsection{Regulation of megalin $m R N A$ and protein expression}

In terms of megalin mRNA expression, there have been several studies investigating the megalin promoter. The transcription factor $\mathrm{Sp} 1$ has been shown to bind a nonconsensus TATA box in the human promoter and play a role in the basal transcription of megalin in parathyroid cells (Knutson et al., 1998). In addition, a sequence from position +5 to +11 , downstream of the transcription initiation site, is important for the topology of the binding site of the transcription factor IID to the megalin promoter in the TATA box region (Knutson et al., 2000a). Megalin expression is also regulated by the methylation of a $\mathrm{CpG}$ island identified in the human promoter, which is correlated with the lack of megalin expression in some cell lines, in contrast to the parathyroid, in which its promoter is unmethylated and megalin is expressed (Knutson et al., $2000 \mathrm{~b})$. In the rat megalin promoter, a proximal Sp1 site and a JCV repeat are important for activating transcription (Zhao et al., 2001).

Our group has been working on understanding the regulation of megalin expression at transcriptional level under different stimulus. Considering the protective roles that PPARs and their agonists have, for example, in renal disease we started analyzing if megalin could be a target of these nuclear receptors. Through analyzing the megalin promoter, we identified three consensus sites for peroxisome proliferator- 
activated receptor (PPAR) that directly bind PPAR $\alpha$ and PPAR $\gamma$ but not PPAR $\beta / \delta$. Moreover, the treatment of PT cells with PPAR $\alpha$ and $\gamma$ agonists induces significant increases in megalin mRNA and protein expression, an effect that is counteracted by specific antagonists for the nuclear receptors. Finally, PPARs also regulate the expression of megalin in vivo in mouse and rat kidney (Cabezas et al., 2011). In addition, the treatment of mice with rosiglitazone, a PPAR $\gamma$ agonist, induced a significant increase in megalin expression in the gallbladder and, interestingly, this treatment also rescued the reduction in megalin expression that results from feeding animals a lithogenic diet (Fig. 4B-C). PPAR $\alpha$ and $\gamma$ and their agonists are important players in several systems during development and in the adult, including lipid metabolism, adipose tissue and bone differentiation; they also exert protective effects against pathologies such as diabetic nephropathy, obesity and hypertension (Kostadinova et al., 2005; Zhang and Guan, 2005; Chetty and Sharma, 2006; Drew et al., 2006; Kepez et al., 2006; Semple et al., 2006). As previously noted, megalin is known to play a role in several of the above systems, which makes the receptor an important element to consider when analyzing the broader functions of PPARs.

Bile acids can modulate the expression of megalin at the protein level in PT cells in vitro as well in gallbladder in vivo (Erranz et al., 2004). Recent unpublished data from our laboratory indicate that the nuclear receptor FXR could be responsible for mediating the activating effects of bile acids on megalin expression, as receptor levels in the kidneys of FXR $\mathrm{KO}$ mice were significantly decreased compared to controls (Fig. 4D) and the specific FXR activator GW4064 upregulated megalin mRNA expression in gallbladder epithelial cells cells in culture as well in vivo in mice.

Although there are few known regulators of megalin expression, it is notable that several of the molecules that affect megalin mRNA and/or protein levels also are ligands of the receptor, and their levels and availability are regulated by megalin itself. At the transcriptional level, megalin mRNA expression is augmented by retinoic acid (vitamin A) and vitamin D treatment in cells from different origins and species (Liu et al., 1998). Both vitamins A and D carried by their specific vitamin binding proteins, RBP and DBP, are endocytosed by megalin. In breast cancer cells, the expression of megalin, its coreceptor cubilin and the adaptor protein Dab2 are induced by retinoic acid (Chlon et al., 2008). The differentiation state of cells, such as rat PT cells and F9 embryonal carcinoma cells, also positively regulates the expression of megalin (Liu et al., 1998). For example, the differentiation of F9 cells with retinoic acid and cAMP induces the expression of megalin protein and of the RAP (Czekay et al., 1995). Clusterin/apoJ provides another example of regulation of megalin by its own ligand (Ammar and Closset, 2008). This glycoprotein can act as an apoptosis inducer or inhibitor and is involved in pathologies including cancer and Alzheimer's disease (Zlokovic, 1996; Ammar and Closset, 2008; Nuutinen et al., 2009). The antiapoptotic role of clusterin in prostatic cells is achieved through a megalin-mediated signaling process involving the activation of PI3K/AKT (Ammar and Closset, 2008). Interestingly, clusterin increases megalin mRNA and protein expression (Ammar and Closset, 2008).

In contrast to clusterin, the signaling molecule angiotensin II, which signals through the ATR1 receptor but also binds to and can be internalized by megalin (Gonzalez-Villalobos et al., 2005), negatively regulates receptor expression at both the mRNA and protein levels (Hosojima et al., 2009). Interestingly, the deleterious effect of angiotensin II can be counteracted by insulin, another megalin ligand (Orlando et al., 1998), partly through the inhibition of the ERK pathway by ATR1 activation, downstream of the IRS/PI3K signaling pathway (Hosojima et al., 2009). We also have evidence of the protective role of ATR1 antagonists on megalin expression in vivo. The treatment of rats with losartan, an ATR1 antagonist, can protect against the reduction of megalin induced by daily injections of BSA (1g/100 body weight) for one week (Fig. 5). It has been suggested that the reduction of megalin in diabetic nephropathy, which is also characterized by albuminuria and fibrosis, could be mediated by toxic levels of albumin (CarusoNeves et al., 2006) and/or by the cytokine TGF $\beta$, which can be induced by albumin treatment in vitro (Gekle et al., 2003; Diwakar et al., 2007). Whether the megalin promoter is directly regulated by this cytokine through the $\operatorname{Smad} 2 / 3$ pathway is not known.

\subsection{Regulation of megalin protein levels and cell surface expression}

Besides the regulation of megalin mRNA levels, there are other mechanisms controlling the availability of the receptor. Various molecules and processes also regulate the levels of megalin protein and its availability at the cell surface. As previously mentioned, megalin folding requires the assistance of RAP (Farquhar et al., 1995), a chaperone that acts in the lumen of the ER, specifically in the ligand binding repeats. This action probably functions to avoid premature binding of ligands that are synthesized in the same cell, as has been

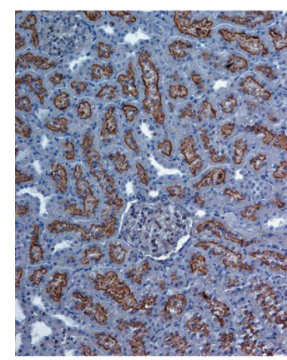

Control

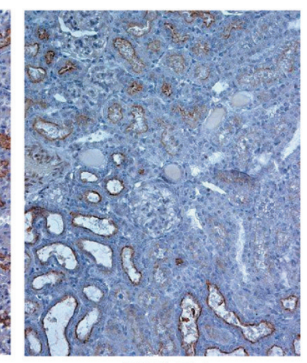

BSA 7d $(1 \mathrm{~g} / 100 \mathrm{~g}$ bw)

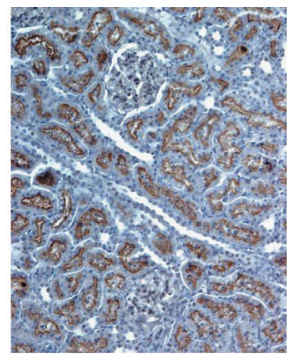

BSA 7d

(1g/100g bw + Losartan)
Figure 5. The angiotensin II receptor I inhibitor losartan protects against the reduction of megalin in kidney of rats subjected to BSA-induced tubulointerstitial damage and proteinuria. Sprague- Dawly rats were divided in three groups of four animals each. The control group was intraperitoneally injected with saline for seven days. The BSA group received BSA (1g/100 gr BW/day; intraperitoneal injections) for seven days. The last group received Losartan $(40 \mathrm{mg} / \mathrm{kg} / \mathrm{day})$ administered by gavage for four days and then losartan was given simultaneously with BSA (1g/100 gr BW/day; intraperitoneal injections) for seven days. At the end of this period, the animals were euthanized, and kidneys were extracted and fixed to perform inmunohistochemistry to detect megalin, as previously described (Erranz et al., 2004; Cabezas et al., 2011). BSA injections alone reduced megalin immunostaining, and this reduction was rescued by simultaneous treatment with losartan. 
described for LRP1 (Bu and Marzolo, 2000). The importance of RAP in megalin protein expression is clearly illustrated by the phenotype of RAP KO mice (Birn et al., 2000). These animals express $23 \%$ of normal levels of megalin in the renal PT and exhibit other phenotypes consistent with a lack of megalin, such as LMW proteinuria and the urinary excretion of $\alpha$-amylase and DBP (Birn et al., 2000; Lisi et al., 2008). The absence of RAP also results in reduction of megalin levels in the thyroid, resulting in defects in thyroglobulin secretion into the colloid and moderate increases in the levels of thyroid-stimulating hormone (Lisi et al., 2006). In addition to the ligand binding domains, the folding of the $\beta$-propellers/ EGF domains are also assisted by a chaperone, MESD. MESD is an ER-resident protein that facilitates the correct folding and surface expression of the LRP5/LRP6 receptors, which are responsible for the Wnt/ $\beta$-catenin pathway (Koduri and Blacklow, 2007), as well as megalin (Lighthouse et al., 2010). Accordingly, mice KO for MESD exhibit a reduction in megalin at the surface of the visceral endoderm and an accumulation of the receptor in intracellular compartments (Lighthouse et al., 2010).

The cytosolic adaptor protein Dab2, which binds to the cytosolic domain of megalin (Oleinikov et al., 2000), is also important in the expression and function of megalin during development (Maurer and Cooper, 2005) and in adult tissues (Nagai et al., 2005). This protein is critical for embryo development, as it is required for nutrient internalization by the visceral endoderm, where megalin is expressed (Morris et al., 2002). The loss of Dab2 is also associated with a loss of cell surface polarity of megalin and E-cadherin and the formation of the primitive endoderm outer layer in embryoid bodies (Yang et al., 2007). Adult Dab2 conditional KO mice show excretion of proteins such as DBP in the urine, a reduction in total megalin expression and the redistribution of the receptor from intracellular vesicles and endosomal compartments to microvilli at the apical surface of PT cells (Morris et al., 2002; Nagai et al., 2005).

Megalin expression and trafficking are also dependent upon modifications in the cytoplasmic domain of the receptor. Specifically, the phosphorylation of the megalin cytoplasmic domain by GSK3 (Fig. 6) is able to decrease its cell surface expression by a negative regulation of megalin recycling without changing its apical distribution or endocytosis (Yuseff et al., 2007). The serine within the PPPSP motif constitutes the main phosphosite in the megalin cytoplasmic tail. This motif seems not to act as a priming site for other phosphorylation events, as the phosphomimetic PPPDP mutant receptor is not as highly phosphorylated as the wild type and shows a level of phosphorylation similar to the PPPAP mutant (Fig. 6B). GSK3 binds directly to megalin tail (Fig. 6C) and phosphorylates the receptor cytoplasmic domain independently of the presence of the megalin ectodomain (Fig. 6D). This modification of megalin could enable signaling pathways that have GSK3 as target for activation or inactivation to regulate the activity of the receptor by affecting its cell surface expression. Among these pathways, some are triggered by signaling molecules that are megalin ligands, such as insulin, IGF-I and Shh, and others by pathways that are related to megalin, such as Wnt/ $\beta$-catenin, which requires LRP5/ 6 and MESD. Moreover, as previously discussed, the adaptor protein APPL1 which has a role in signaling endosomes related to AKT activation
(Schenck et al., 2008; Zhao and Guan, 2008; Cheng et al., 2009), links the megalin cytoplasmic domain to OCRL, which is mutated in patients with Lowe Syndrome. The apical distribution of megalin is not affected by the downregulation or mutation of OCRL, but its cell surface expression and recycling are significantly decreased (Vicinanza $M$ et al, manuscript in preparation). This opens the possibility that the phosphorylation of megalin may be also affected in Lowe Syndrome and Dent-2 patients, which could partially account for the disease phenotypes. Finally, the ligand clustering/apoJ also modulates the receptor's phosphorylation, possibly on a tyrosine residue of the cytoplasmic tail (Ammar and Closset, 2008). How this phosphorylation regulates megalin function and/or trafficking is as yet unknown.

As has been described for other members of the LDLR family and for APP (Marzolo and Bu, 2009), megalin is also a substrate for metalloproteases or sheddases, which induce ectodomain shedding that produces a carboxy-terminal fragment, which is then subject to receptor intramembrane proteolysis by the $\gamma$-secretase complex (Zou Z et al., 2004; Biemesderfer, 2006). It has been suggested that after processing by the $\gamma$-secretase complex, the resultant megalin intracellular domain, or MICD, could travel to the nucleus and play a transcriptional regulatory role, decreasing the expression of megalin and other megalin-regulated proteins in PT cells, such as NHE3 ( $\mathrm{Li}$ et al., 2008). The transcriptional role of the MICD has been recently challenged by in vivo data from transgenic mice expressing MICD (Christ et al., 2010). These animals did not show decreases in megalin protein or effects on the endocytic function of renal PT. However, it is important to note that the construct used in this report has three Flag epitopes that could affect the nuclear expression of the MICD, which, in fact, was not detected in the nuclei of PT cells. Therefore, regarding the production of MICD that has been reported in vitro, whether it is produced in vivo and the potential roles of this fragment are still controversial aspects to solve. However, the kidney is not the only organ in which this type of processing may occur. In fact, megalin nuclear staining in the oligodendrocytes in the spinal cord white matter of embryonic and adult mice has been reported (Wicher et al., 2006). In addition, megalin can be found in several fragments of human gallbladder epithelial cells, suggesting proteolysis (Erranz et al., 2004), and nuclear staining can be seen using an antibody that recognizes the human cytoplasmic domain (Fig. 4A). Together, these findings suggest that megalin processing could be physiologically relevant in, for example, the regulation of megalin half-life. The next steps in this line of investigation should focus on the mechanisms that regulate proteolytic processing of megalin, the roles of its ligands that have signaling properties and megalin's intracellular adaptor or interacting proteins, as have been studied for APP and other receptors of the LDLR family (Marzolo and $\mathrm{Bu}, 2009$ ).

It has been shown that the urine normally contains microvesicles or exosomes, membrane particles of 40 to 100 $\mathrm{nm}$ secreted from renal epithelial cells after the fusion of multivesicular bodies with the luminal plasma membrane (Pisitkun et al., 2004; Keller et al., 2006; Knepper and Pisitkun, 2007; Dimov et al., 2009). Megalin and cubilin are among the several components contained in urine-derived exosomes (Pisitkun et al., 2004). In some disease conditions, including chronic renal diseases, the exosome protein profile is altered 
(Zhou et al., 2008; Gonzales et al., 2009). However, until now, there has been no report indicating changes in the presence of megalin in exosomes in different diseases, such as Dent Disease or Lowe Syndrome, diabetic nephropathy or megalin KO mouse models. Dent and Lowe patients are reported to have lower levels of urine megalin (Norden et al., 2002), but the method used in this study did not discriminate between megalin associated with exosomes and megalin derived from protease-mediated shedding of the extracellular domain (Fernandez-Llama et al., 2010). It is therefore possible that under some pathophysiological conditions, the levels of megalin secreted in exosomes could be affected and could serve a diagnostic biomarker. Because exosomes are secreted from almost all cells, it is also possible that in other organs, as well as the kidney, exosomes containing megalin could be a physiological mechanism to regulate the availability of ligands and / or to transport ligands from one cell to another.

\section{CONCLUSIONS}

Since the discovery of megalin/LRP2 as an important endocytic receptor present in the epithelial cells of the kidney PT several new ligands and functions for this protein have been uncovered. In addition to its role in the internalization of different molecules, the possibility that megalin is a target and/or regulator of signal transduction pathways, as well as the emergence of its roles in neurodegeneration and regeneration processes and in chronic and genetic diseases, underscores the importance of understanding the mechanisms that regulate megalin expression and functions.

At mRNA level megalin expression is regulated positively by retinoic acid, vitamin D, bile acids and ligands of PPAR $\alpha$ and $\gamma$. The presence of the receptor at the cell surface is under the control of the ER chaperones RAP and MESD and membrane trafficking mechanisms including megalin internalization
A

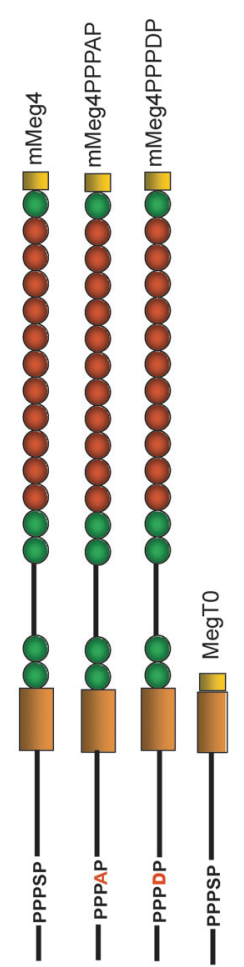

HA Epitope

Ligand binding repeats

EGF-like repeats

Transmembrane domain
B

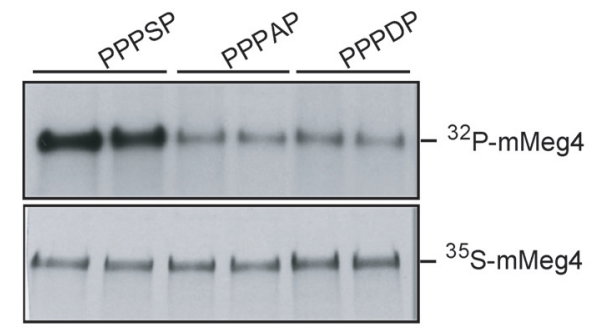

C

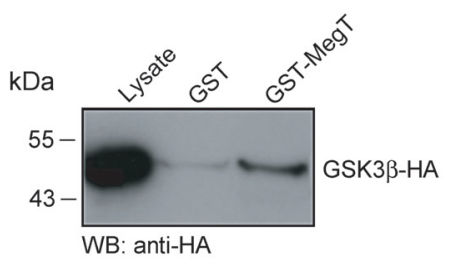

D

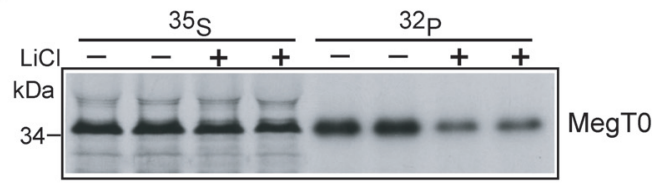

Figure 6. Megalin phosphorylation in the PPPSP cytoplasmic motif is mediated by GSK3 and does not require the receptor ectodomain. a) Schematic representation of megalin minireceptors containing the fourth ligand binding, transmembrane and cytosolic domains of human megalin, with an amino-terminal HA epitope (mMeg4); MegT lacks the ectomain. b) Minireceptors with wildtype or mutant (PPPAP or PPPDP) cytoplasmic domains were expressed in MDCK cells. Cells were metabolically labeled either with ${ }^{35} \mathrm{~S}$-methionine/cysteine or ${ }^{32} \mathrm{P}$-orthophosphate for 4 or $2 \mathrm{~h}$ respectively. After cell lysis, proteins were immunoprecipitated and resolved by SDS-PAGE and autoradiography. The presence of the serine residue within the PPPSP motif was critical for the phosphorylation of the minireceptor. c) HEK-293 cells were transfected with GSK3-HA, and the cell lysates were subject to pull-down assays with GSTmegalin cytoplasmic domain (GST-MegT) or GST alone as a control. The megalin cytoplasmic domain interacts with GSK3. d) MegT was transfected in MDCK cells and the cells were metabolically labeled as in b) but in the presence or in the absence of LiCl, to inhibit GSK3. Phosphorylation of this construct indicated that this modification does not require the megalin ectodomain and is mediated by GSK3 because it decreased significantly in the presence of $\mathrm{LiCl}$ compared to the control $(\mathrm{NaCl})$. 
and recycling dependent on the interaction of its cytoplasmic domain with adaptor/cytosolic proteins and the kinase GSK3. Finally, two still poorly understood processes, megalin's proteolytic processing and the secretion of the receptor in exosomes could be also relevant mechanisms controlling the availability of the receptor and its function at the cell surface.

\section{ACKNOWLEDGMENTS}

We thank Dr. Juan Francisco Miquel from the Departamento de Gastroenterología, Facultad de Medicina, PUC and Francisco Gomez for their collaboration and technical support in the experiments on gallbladder cells in primary culture and Dr. Carlos Vio and Carlos Céspedes from the Departamento de Ciencias Fisiológicas, Facultad de Ciencias Biológicas, PUC, for their collaboration in the experiments in losartan- treated rats. We also thank Dr. Marco Arrese from the Departamento de Gastroenterología, Facultad de Medicina, PUC, for providing the kidneys from FXR null and control animals. This work is supported by the Fondo Nacional de Ciencia y Tecnología, FONDECYT, grant \# 1070373 and the Millenium Nucleus in Regenerative Biology (MINREB).

\section{REFERENCES}

AMBJORN M, ASMUSSEN JW, LINDSTAM M, GOTFRYD K, JACOBSEN C, KISELYOV VV, MOESTRUP SK, PENKOWA M, BOCK E, BEREZIN V (2008) Metallothionein and a peptide modeled after metallothionein, EmtinB, induce neuronal differentiation and survival through binding to receptors of the low-density lipoprotein receptor family. J Neurochem 104: 21-37

AMMAR H, CLOSSET JL (2008) Clusterin activates survival through the phosphatidylinositol 3-kinase/Akt pathway. J Biol Chem 283: 1285112861.

ANANYEVA NM, MAKOGONENKO YM, SARAFANOV AG, PECHIK IV, GORLATOVA N, RADTKE KP, SHIMA M, SAENKO EL (2008) Interaction of coagulation factor VIII with members of the low-density lipoprotein receptor family follows common mechanism and involves consensus residues within the A2 binding site 484-509. Blood Coagul Fibrinolysis 19: 543-555

ANTEQUERA D, VARGAS T, UGALDE C, SPUCH C, MOLINA JA, FERRER I, BERMEJO-PAREJA F, CARRO E (2009) Cytoplasmic gelsolin increases mitochondrial activity and reduces Abeta burden in a mouse model of Alzheimer's disease. Neurobiol Dis 36: 42-50.

ASSEMAT E, CHATELET F, CHANDELLIER J, COMMO F, CASES O, VERROUST P, KOZYRAKI R (2005a) Overlapping expression patterns of the multiligand endocytic receptors cubilin and megalin in the CNS, sensory organs and developing epithelia of the rodent embryo. Gene Expr Patterns 6: 69-78.

ASSEMAT E, VINOT S, GOFFLOT F, LINSEL-NITSCHKE P, ILLIEN F, CHATELET F, VERROUST P, LOUVET-VALLEE S, RINNINGER F, KOZYRAKI R (2005b) Expression and role of cubilin in the internalization of nutrients during the peri-implantation development of the rodent embryo. Biol Reprod 72: 1079-1086.

BANSAL AGIERASCH LM (1991) The NPXY internalization signal of the LDL receptor adopts a reverse-turn conformation. Cell 67: 1195-1201.

BATUMAN V, VERROUST PJ, NAVAR GL, KAYSEN JH, GODA FO, CAMPBELL WC, SIMON E, PONTILLON F, LYLES M, BRUNO J, HAMMOND TG (1998) Myeloma light chains are ligands for cubilin (gp280). Am J Physiol Renal Physiol 275: F246-F254.

BELL RD, SAGARE AP, FRIEDMAN AE, BEDI GS, HOLTZMAN DM, DEANE R, ZLOKOVIC BV (2007) Transport pathways for clearance of human Alzheimer's amyloid beta-peptide and apolipoproteins $\mathrm{E}$ and $\mathrm{J}$ in the mouse central nervous system. J Cereb Blood Flow Metab 27: 909-918.

BENTO-ABREU A, VELASCO A, POLO-HERNÁNDEZ E, LILLO C, KOZYRAKI R, TABERNERO AMEDINA JM (2009) Albumin endocytosis via megalin in astrocytes is caveola- and Dab-1 dependent and is required for the synthesis of the neurotrophic factor oleic acid. J Neurochem 111: 49-60.
BIEMESDERFER D, NAGY T, DE GRAY B, ARONSON PS (1999) Specific association of megalin and the $\mathrm{Na}+\mathrm{H}+$ exchanger isoform NHE3 in the proximal tubule. J Biol Chem 274: 17518-17524.

BIEMESDERFER D, DE GRAY B, ARONSON PS (2001) Active (9.6 s) and inactive (21 s) oligomers of NHE3 in microdomains of the renal brush border. J Biol Chem 276: 10161-10167.

BIEMESDERFER D (2006) Regulated intramembrane proteolysis of megalin: linking urinary protein and gene regulation in proximal tubule? Kidney Int 69: 1717-1721.

BIRN H, VERROUST PJ, NEXØ E, HAGER H, JACOBSEN C, CHRISTENSEN EI, MOESTRUP SK (1997) Characterization of an epithelial approximately 460-kDa protein that facilitates endocytosis of intrinsic factor-vitamin B12 and binds receptor-associated protein. J Biol Chem 272: 26497-26504.

BIRN H, VORUM H, VERROUST PJ, MOESTRUP SK, CHRISTENSEN EI (2000a) Receptor-associated protein is important for normal processing of megalin in kidney proximal tubules. J Am Soc Nephrol 11: 191-202.

BIRN H, FYFE JC, JACOBSEN C, MOUNIER F, VERROUST PJ, ØRSKOV H, WILLNOW TE, MOESTRUP SK, CHRISTENSEN EI (2000b) Cubilin is an albumin binding protein important for renal tubular albumin reabsorption. J Clin Invest 105: 1353-1361.

BIRN H, ZHAI X, HOLM J, HANSEN SI, JACOBSEN C, CHRISTENSEN EI, MOESTRUP SK (2005) Megalin binds and mediates cellular internalization of folate binding protein. FEBS J 272: 4423-4430.

BOCKENHAUER D, BOKENKAMP A, VAN'T HOFF W, LEVTCHENKO E, KIST-VAN HOLTHE JE, TASIC V, LUDWIG M (2008) Renal phenotype in Lowe Syndrome: a selective proximal tubular dysfunction. Clin J Am Soc Nephrol 3: 1430-1436.

BOLOS M, FERNÁNDEZ S, TORRES-ALEMÁN I (2010) Oral administration of a GSK3 inhibitor increases brain insulin-like growth factor I levels. J Biol Chem 285: 17693-17700.

BONNARD AS, CHAN P, FONTAINE M (1997) Expression of clusterin and $\mathrm{C} 4 \mathrm{mRNA}$ during rat peripheral nerve regeneration. Immunopharmacology 38: 81-86.

BOTHWELL SP, CHAN E, BERNARDINI IM, KUO YM, GAHL WA, NUSSBAUM RL (2010) Mouse Model for Lowe Syndrome/Dent Disease 2 Renal Tubulopathy. J Am Soc Nephrol.

BOUCHARD G, NELSON HM, LAMMERT F, ROWE LB, CAREY MCPAIGEN B (1999) High-resolution maps of the murine Chromosome 2 region containing the cholesterol gallstone locus, Lith1. Mamm Genome 10: 1070-1074.

BU G, MARZOLO MP (2000) Role of rap in the biogenesis of lipoprotein receptors. Trends Cardiovasc Med 10: 148-155.

BURMEISTER R, BOE IM, NYKJAER A, JACOBSEN C, MOESTRUP SK, VERROUST P, CHRISTENSEN EI, LUND J, WILLNOW TE (2001) A tworeceptor pathway for catabolism of Clara cell secretory protein in the kidney. J Biol Chem 276: 13295-13301.

CABEZAS F, LAGOS J, CÉSPEDES C, VIO C, BRONFMAN M, MARZOLO M P (2011) Megalin/LRP2 Expression is Induced by Peroxisome Proliferator-activated Receptor -Alpha and -Gamma: Implications for PPARs` Roles in Renal Function. PLoS ONE 6: e16794.

CALERO M, TOKUDA T, ROSTAGNO A, KUMAR A, ZLOKOVIC B, FRANGIONE B, GHISO J (1999) Functional and structural properties of lipid-associated apolipoprotein J (clusterin). Biochem J 344 Pt 2: 375-383.

CARRO E, SPUCH C, TREJO JL, ANTEQUERA D, TORRES-ALEMAN I (2005) Choroid plexus megalin is involved in neuroprotection by serum insulin-like growth factor I. J Neurosci 25: 10884-10893.

CARUSO-NEVES C, PINHEIRO AA, CAI H, SOUZA-MENEZES J, GUGGINO WB (2006) PKB and megalin determine the survival or death of renal proximal tubule cells. Proc Natl Acad Sci U S A 103: 1881018815.

CHAN WL, SHAW PC, TAM SC, JACOBSEN C, GLIEMANN J, NIELSEN MS (2000) Trichosanthin interacts with and enters cells via LDL receptor family members. Biochem Biophys Res Commun 270: 453-457.

CHENG KK, IGLESIAS MA, LAM KS, WANG Y, SWEENEY G, ZHU W, VANHOUTTE PM, KRAEGEN EW, XU A (2009) APPL1 potentiates insulin-mediated inhibition of hepatic glucose production and alleviates diabetes via Akt activation in mice. Cell Metab 9: 417-427.

CHETTY VT, SHARMA AM (2006) Can PPARgamma agonists have a role in the management of obesity-related hypertension? Vascul Pharmacol 45: 46-53.

CHIU-UGALDE J, THEILIG F, BEHRENDS T, DREBES J, SIELAND C, SUBBARAYAL P, KOHRLE J, HAMMES A, SCHOMBURG L, SCHWEIZER U (2010) Mutation of megalin leads to urinary loss of selenoprotein $\mathrm{P}$ and selenium deficiency in serum, liver, kidneys and brain. Biochem J 431: 103-111. 
CHLON TM, TAFFANY DA, WELSH JROWLING MJ (2008) Retinoids modulate expression of the endocytic partners megalin, cubilin, and disabled-2 and uptake of vitamin D-binding protein in human mammary cells. J Nutr 138: 1323-1328.

CHO HY, LEE BH, CHOI HJ, HA IS, CHOI Y, CHEONG HI (2008) Renal manifestations of Dent disease and Lowe syndrome. Pediatr Nephrol 23: 243-249.

CHRIST A, TERRYN S, SCHMIDT V, CHRISTENSEN EI, HUSKA MR, ANDRADE-NAVARRO MA, HUBNER N, DEVUYST O, HAMMES A, WILLNOW TE (2010) The soluble intracellular domain of megalin does not affect renal proximal tubular function in vivo. Kidney Int 78: 473-477.

CHRISTENSEN EI, GLIEMANN J, MOESTRUP SK (1992) Renal tubule gp330 is a calcium binding receptor for endocytic uptake of protein. J Histochem Cytochem 40: 1481-1490.

CHRISTENSEN EI, MOSKAUG JO, VORUM H, JACOBSEN C, GUNDERSEN TE, NYKJAER A, BLOMHOFF R, WILLNOW TE, MOESTRUP SK (1999) Evidence for an essential role of megalin in transepithelial transport of retinol. J Am Soc Nephrol 10: 685-695.

CHRISTENSEN EI, WILLNOW TE (1999) Essential role of megalin in renal proximal tubule for vitamin homeostasis. J Am Soc Nephrol 10: 22242236.

CHRISTENSEN EI, ZHOU Q, SØRENSEN SS, RASMUSSEN AK, JACOBSEN C, FELDT-RASMUSSEN U, NIELSEN R (2007) Distribution of alphagalactosidase $\mathrm{A}$ in normal human kidney and renal accumulation and distribution of recombinant alpha-galactosidase A in Fabry mice. J Am Soc Nephrol 18: 698-706.

CHRISTOFFERSEN C, DAHLBACK B, NIELSEN LB (2006) Apolipoprotein $\mathrm{M}$ : progress in understanding its regulation and metabolic functions. Scand J Clin Lab Invest 66: 631-637.

CHUN JT, WANG L, PASINETTI GM, FINCH CE, ZLOKOVIC BV (1999) Glycoprotein 330/megalin (LRP-2) has low prevalence as mRNA and protein in brain microvessels and choroid plexus. Exp Neurol 157: 194201.

CHUNG RS, PENKOWA M, DITTMANN J, KING CE, BARTLETT C, ASMUSSEN JW, HIDALGO J, CARRASCO J, LEUNG YK, WALKER AK, FUNG SJ, DUNLOP SA, FITZGERALD M, BEAZLEY LD, CHUAH MI, VICKERS JC, WEST AK (2008) Redefining the role of metallothionein within the injured brain: extracellular metallothioneins play an important role in the astrocyte-neuron response to injury. J Biol Chem 283: 15349-15358.

COLOMBANI V, SILVIANI V, MARTEAU C, LERIQUE B, CARTOUZOU G, GEROLAMI A (1996) Presence of the NHE3 isoform of the Na+/H+ exchanger in human gallbladder. Clin Sci (Lond) 91: 209-212.

CUI S, VERROUST PJ, MOESTRUP SK, CHRISTENSEN EI (1996) Megalin/ gp330 mediates uptake of albumin in renal proximal tubule. Am J Physiol 271: F900-907.

CULI J, SPRINGER TA,MANN RS (2004) Boca-dependent maturation of beta-propeller/EGF modules in low-density lipoprotein receptor proteins. Embo J 23: 1372-1380.

CZEKAY RP, ORLANDO RA, WOODWARD L, ADAMSON ED, FARQUHAR MG (1995) The expression of megalin (gp330) and LRP diverges during F9 cell differentiation. J Cell Sci 108 (Pt 4): 1433-1441.

DAHLBACK B, NIELSEN LB (2006) Apolipoprotein M--a novel player in high-density lipoprotein metabolism and atherosclerosis. Curr Opin Lipidol 17: 291-295.

DAHLBACK B, NIELSEN LB (2009) Apolipoprotein M affecting lipid metabolism or just catching a ride with lipoproteins in the circulation? Cell Mol Life Sci 66: 559-564.

DIETRICH MO, SPUCH C, ANTEQUERA D, RODAL I, DE YEBENES JG, MOLINA JA, BERMEJO F, CARRO E (2008) Megalin mediates the transport of leptin across the blood-CSF barrier. Neurobiol Aging 29: 902-912.

DIMOV I, JANKOVIC VELICKOVIC L, STEFANOVIC V (2009) Urinary exosomes. Scientific World Journal 9: 1107-1118.

DIWAKAR R, PEARSON AL, COLVILLE-NASH P, BRUNSKILL NJ, DOCKRELL ME (2007) The role played by endocytosis in albumininduced secretion of TGF-beta1 by proximal tubular epithelial cells. Am J Physiol Renal Physiol 292: F1464-1470.

DONOSO M, CANCINO J, LEE J, VAN KERKHOF P, RETAMAL C, BU G, GONZALEZ A, CACERES A MARZOLO MP (2009) Polarized traffic of LRP1 involves AP1B and SNX17 operating on Y-dependent sorting motifs in different pathways. Mol Biol Cell 20: 481-497.

DREW PD, XU J, STORER PD, CHAVIS JA, RACKE MK (2006) Peroxisome proliferator-activated receptor agonist regulation of glial activation: Relevance to CNS inflammatory disorders. Neurochem Int 49: 183-189.
DUGUE-PUJOL $S$, ROUSSET $X$, CHATEAU D, PASTIER D, KLEIN C, DEMEURIE J, CYWINER-GOLENZER C, CHABERT M, VERROUST P, CHAMBAZ J, CHATELET FP, KALOPISSIS AD (2007) Apolipoprotein A-II is catabolized in the kidney as a function of its plasma concentration. J Lipid Res 48: 2151-2161.

ERDMANN KS, MAO Y, MCCREA HJ, ZONCU R, LEE S, PARADISE S, MODREGGER J, BIEMESDERFER D, TOOMRE D, DE CAMILLI $P$ (2007) A role of the Lowe syndrome protein OCRL in early steps of the endocytic pathway. Dev Cell 13: 377-390.

ERRANZ B, MIOUEL JF, ARGRAVES WS, BARTH JL, PIMENTEL F, MARZOLO MP (2004) Megalin and cubilin expression in gallbladder epithelium and regulation by bile acids. J Lipid Res 45: 2185-2198.

FABER K, HVIDBERG V, MOESTRUP SK, DAHLBACK B, NIELSEN LB (2006) Megalin is a receptor for apolipoprotein $\mathrm{M}$, and kidney-specific megalin-deficiency confers urinary excretion of apolipoprotein $\mathrm{M}$. Mol Endocrinol 20: 212-218.

FARQUHAR MG, SAITO A, KERJASCHKI D, ORLANDO RA (1995) The Heymann nephritis antigenic complex: megalin (gp330) and RAP. J Am Soc Nephrol 6: 35-47.

FERNÁNDEZ-LLAMA P, KHOSITSETH S, GONZALES PA, STAR RA PISITKUN T, KNEPPER MA (2010) Tamm-Horsfall protein and urinary exosome isolation. Kidney Int 77: 736-742.

FISHER CE, HOWIE SE (2006) The role of megalin (LRP-2/Gp330) during development. Dev Biol 296: 279-297.

FITZGERALD M, NAIRN P, BARTLETT CA, CHUNG RS, WEST AK, BEAZLEY LD (2007) Metallothionein-IIA promotes neurite growth via the megalin receptor. Exp Brain Res 183: 171-180.

FLEMING CE, MAR FM, FRANQUINHO F, SARAIVA MJ, SOUSA MM (2009a) Transthyretin internalization by sensory neurons is megalin mediated and necessary for its neuritogenic activity. J Neurosci 29: 32203232.

FLEMING CE, MAR FM, FRANQUINHO F, SOUSA MM (2009b) Chapter 17: Transthyretin: an enhancer of nerve regeneration. Int Rev Neurobiol 87: 337-346.

GAJERA CR, EMICH H, LIOUBINSKI O, CHRIST A, BECKERVORDERSANDFORTH-BONK R, YOSHIKAWA K, BACHMANN S, CHRISTENSEN EI, GOTZ M, KEMPERMANN G, PETERSON AS, WILLNOW TE, HAMMES A (2010) LRP2 in ependymal cells regulates BMP signaling in the adult neurogenic niche. J Cell Sci 123: 1922-1930.

GBUREK J, VERROUST PJ, WILLNOW TE, FYFE JC, NOWACKI W, JACOBSEN C, MOESTRUP SK, CHRISTENSEN EI (2002) Megalin and cubilin are endocytic receptors involved in renal clearance of hemoglobin. J Am Soc Nephrol 13: 423-430.

GBUREK J, BIRN H, VERROUST PJ, GOJ B, JACOBSEN C, MOESTRUP SK, WILLNOW TE, CHRISTENSEN EI (2003) Renal uptake of myoglobin is mediated by the endocytic receptors megalin and cubilin. Am J Physiol Renal Physiol 285: F451-458

GEKLE M, KNAUS P, NIELSEN R, MILDENBERGER S, FREUDINGER R, WOHLFARTH V, SAUVANT C, CHRISTENSEN EI (2003) Transforming growth factor-beta1 reduces megalin- and cubilin-mediated endocytosis of albumin in proximal-tubule-derived opossum kidney cells. J Physiol 552: $471-481$

GERRITSEN KG, PETERS HP, NGUYEN TQ, KOENERS MP, WETZELS JF, JOLES JA, CHRISTENSEN EI, VERROUST PJ, LI D, OLIVER N, XU L, KOK RJ, GOLDSCHMEDING R (2010) Renal proximal tubular dysfunction is a major determinant of urinary connective tissue growth factor excretion. Am J Physiol Renal Physiol 298: F1457-1464.

GONZALES PA, PISITKUN T, HOFFERT JD, TCHAPYJNIKOV D, STAR RA, KLETA R, WANG NS, KNEPPER MA (2009) Large-scale proteomics and phosphoproteomics of urinary exosomes. J Am Soc Nephrol 20: 363-379.

GONZÁLEZ-VILLALOBOS R, KLASSEN RB, ALLEN PL, NAVAR LG, HAMMOND TG (2005) Megalin binds and internalizes angiotensin II. Am J Physiol Renal Physiol 288: F420-427.

GONZÁLEZ-VILLALOBOS R, KLASSEN RB, ALLEN PL, JOHANSON K, BAKER CB, KOBORI H, NAVAR LG, HAMMOND TG (2006) Megalin binds and internalizes angiotensin-(1-7). Am J Physiol Renal Physiol 290: F1270-1275.

GRESSNER OA, LAHME B, GRESSNER AM (2008) Gc-globulin (vitamin $\mathrm{D}$ binding protein) is synthesized and secreted by hepatocytes and internalized by hepatic stellate cells through $\mathrm{Ca}(2+)$-dependent interaction with the megalin/gp330 receptor. Clin Chim Acta 390: 28-37.

GUGGINO SE (2007) Mechanisms of disease: what can mouse models tell us about the molecular processes underlying Dent disease? Nat Clin Pract Nephrol 3: 449-455

HAMA H, SAITO A, TAKEDA T, TANUMA A, XIE Y, SATO K, KAZAMA JJ, GEJYO F (2004) Evidence indicating that renal tubular metabolism 
of leptin is mediated by megalin but not by the leptin receptors. Endocrinology 145: 3935-3940.

HAMMAD SM, RANGANATHAN S, LOUKINOVA E, TWAL WO, ARGRAVES WS (1997) Interaction of apolipoprotein J-amyloid beta-peptide complex with low density lipoprotein receptor-related protein-2/megalin. A mechanism to prevent pathological accumulation of amyloid beta-peptide. J Biol Chem 272: 18644-18649.

HAMMAD SM, STEFANSSON S, TWAL WO, DRAKE CJ, FLEMING P, REMALEY A, BREWER HBJ, ARGRAVES WS (1999) Cubilin, the endocytic receptor for intrinsic factor-vitamin $\mathrm{B}(12)$ complex, mediates high-density lipoprotein holoparticle endocytosis. Proc Natl Acad Sci USA 96: 10158-10163.

HAMMAD SM, BARTH JL, KNAAK C, ARGRAVES WS (2000) Megalin acts in concert with cubilin to mediate endocytosis of high density lipoproteins. J Biol Chem 275: 12003-12008.

HAMMES A, ANDREASSEN TK, SPOELGEN R, RAILA J, HUBNER N, SCHULZ H, METZGER J, SCHWEIGERT FJ, LUPPA PB, NYKJAER A, WILLNOW TE (2005) Role of endocytosis in cellular uptake of sex steroids. Cell 122:751-762.

HERMO L, LUSTIG M, LEFRANCOIS S, ARGRAVES WS, MORALES CR (1999) Expression and regulation of LRP-2/megalin in epithelial cells lining the efferent ducts and epididymis during postnatal development. Mol Reprod Dev 53: 282-293.

HILPERT J, NYKJÆR A, JACOBSEN C, WALLUKAT G, NIELSEN R, MOESTRUP SK, HALLER H, LUFT FC, CHRISTENSEN EI, WILLNOW TE (1999) Megalin antagonizes activation of the parathyroid hormone receptor. J Biol Chem 274: 5620-5625.

HOOPES RR JR, SHRIMPTON AE, KNOHL SJ, HUEBER P, HOPPE B, MATYUS J, SIMCKES A, TASIC V, TOENSHOFF B, SUCHY SF, NUSSBAUM RL, SCHEINMAN SJ (2005) Dent Disease with mutations in OCRL1. Am J Hum Genet 76: 260-267.

HOSOJIMA M, SATO H, YAMAMOTO $K$, KASEDA R, SOMA T, KOBAYASHI A, SUZUKI A, KABASAWA H, TAKEYAMA A, IKUYAMA K, IINO N, NISHIYAMA A, THEKKUMKARA TJ, TAKEDA T, SUZUKI Y, GEJYO F, SAITO A (2009) Regulation of megalin expression in cultured proximal tubule cells by angiotensin II type 1A receptor- and insulin-mediated signaling cross talk. Endocrinology 150: 871-878.

HRYCIW DH, LEE EM, POLLOCK CAPORONNIK P (2004) Molecular changes in proximal tubule function in diabetes mellitus. Clin Exp Pharmacol Physiol 31: 372-379.

HRYCIW DH, EKBERG J, POLLOCK CA, PORONNIK P (2006) CIC-5: a chloride channel with multiple roles in renal tubular albumin uptake. Int J Biochem Cell Biol 38: 1036-1042.

HUSSAIN MM (2001) Structural, biochemical and signaling properties of the low-density lipoprotein receptor gene family. Front Biosci 6: D417-428.

HVIDBERG V, JACOBSEN C, STRONG RK, COWLAND JB, MOESTRUP SK, BORREGAARD N (2005) The endocytic receptor megalin binds the iron transporting neutrophil-gelatinase-associated lipocalin with high affinity and mediates its cellular uptake. FEBS Lett 579: 773-777.

JEON H, MENG W, TAKAGI J, ECK MJ, SPRINGER TA, BLACKLOW SC (2001) Implications for familial hypercholesterolemia from the structure of the LDL receptor YWTD-EGF domain pair. Nat Struct Biol 8: 499-504.

JI L, CHAUHAN V, MEHTA P, WEGIEL J, MEHTA S, CHAUHAN A (2010) Relationship between proteolytically cleaved gelsolin and levels of amyloid-beta protein in the brains of Down syndrome subjects. J Alzheimers Dis 22: 609-617.

KALANTRY S, MANNING S, HAUB O, TOMIHARA-NEWBERGER C, LEE HG, FANGMAN J, DISTECHE CM, MANOVA K, LACY E, (2001).The amnionless gene, essential for mouse gastrulation, encodes a visceralendoderm specific protein with an extracellular cysteine-rich domain. Nat Genet 27: 412-416.

KANALAS JJ, MAKKER SP (1991) Identification of the rat Heymann nephritis autoantigen (GP330) as a receptor site for plasminogen. J Biol Chem 266: 10825-10829.

KANTARCI S, AL-GAZALI L, HILL RS, DONNAI D, BLACK GC, BIETH E, CHASSAING N, LACOMBE D, DEVRIENDT K, TEEBI A LOSCERTALES M, ROBSON C, LIU T, MACLAUGHLIN DT, NOONAN KM, RUSSELL MK, WALSH CA, DONAHOE PKPOBER BR (2007) Mutations in LRP2, which encodes the multiligand receptor megalin, cause Donnai-Barrow and facio-oculo-acoustico-renal syndromes. Nat Genet 39: 957-959.

KANTARCI S, RAGGE NK, THOMAS NS, ROBINSON DO, NOONAN KM, RUSSELL MK, DONNAI D, RAYMOND FL, WALSH CA, DONAHOE PK, POBER BR (2008) Donnai-Barrow syndrome (DBS/FOAR) in a child with a homozygous LRP2 mutation due to complete chromosome 2 paternal isodisomy. Am J Med Genet A 146A: 1842-1847.
KASEDA R, IINO N, HOSOJIMA M, TAKEDA T, HOSAKA K, KOBAYASHI A, YAMAMOTO K, SUZUKI A, KASAI A, SUZUKI Y, GEJYO F, SAITO A (2007) Megalin-mediated endocytosis of cystatin C in proximal tubule cells. Biochem Biophys Res Commun 357: 1130-1134.

KELLER S, SANDERSON MP, STOECK A, ALTEVOGT P (2006) Exosomes: from biogenesis and secretion to biological function. Immunol Lett 107: 102-108.

KEPEZ A, OTO A, DAGDELEN S (2006) Peroxisome proliferator-activated receptor-gamma: novel therapeutic target linking adiposity, insulin resistance, and atherosclerosis. BioDrugs 20: 121-135.

KLASSEN RB, CRENSHAW K, KOZYRAKI R, VERROUST PJ, TIO L, ATRIAN S, ALLEN PL, HAMMOND TG (2004) Megalin mediates renal uptake of heavy metal metallothionein complexes. Am J Physiol Renal Physiol 287: F393-403.

KNEPPER MA, PISITKUN T (2007) Exosomes in urine: who would have thought.? Kidney Int 72: 1043-1045.

KNUTSON A, HELLMAN P, AKERSTROM GWESTIN G (1998) Characterization of the human Megalin/LRP-2 promoter in vitro and in primary parathyroid cells. DNA Cell Biol 17: 551-560.

KNUTSON A, CASTANO E, OELGESCHLAGER T, ROEDER RG, WESTIN G (2000a) Downstream promoter sequences facilitate the formation of a specific transcription factor IID-promoter complex topology required for efficient transcription from the megalin/low density lipoprotein receptor-related protein 2 promoter. J Biol Chem 275: 14190-14197.

KNUTSON A, LILLHAGER P, WESTIN G (2000b) Identification of a CpG island in the human LRP-2 gene and analysis of its methylation status in parathyroid adenomas. Biol Chem 381: 433-438.

KODURI V, BLACKLOW SC (2007) Requirement for natively unstructured regions of mesoderm development candidate 2 in promoting lowdensity lipoprotein receptor-related protein 6 maturation. Biochemistry 46: 6570-6577.

KÖNINGER J, DI MOLA FF, DI SEBASTIANO P, GARDINI A, BRIGSTOCK DR, INNOCENTI P, BÜCHLER MW, FRIESS H (2005) Transforming growth factor-beta pathway is activated in cholecystolithiasis. Langenbecks Arch Surg. 390: 21-28.

KONIG O, RUTTIGER L, MULLER M, ZIMMERMANN U, ERDMANN B, KALBACHER H, GROSS M, KNIPPER M (2008) Estrogen and the inner ear: megalin knockout mice suffer progressive hearing loss. Faseb J 22: 410-417.

KOSTADINOVA R, WAHLI W, MICHALIK L (2005) PPARs in diseases: control mechanisms of inflammation. Curr Med Chem 12: 2995-3009.

KOUNNAS MZ, CHAPPELL DA, STRICKLAND DK, ARGRAVES WS (1993) Glycoprotein 330, a member of the low density lipoproteína receptor family, binds lipoprotein lipase in vitro. J Biol Chem 268: 14176-14181.

KOUNNAS MZ, LOUKINOVA EB, STEFANSSON S, HARMONY JA, BREWER BH, STRICKLAND DK, ARGRAVES WS (1995) Identification of glycoprotein 330 as an endocytic receptor for apolipoprotein J/ clusterin. J Biol Chem 270: 13070-13075.

KOZYRAKI R, FYFE J, KRISTIANSEN M, GERDES C, JACOBSEN C, CUI S, CHRISTENSEN EI, AMINOFF M, DE LA CHAPELLE A, KRAHE R, VERROUST PJ, MOESTRUP SK (1999) The intrinsic factor-vitamin B12 receptor, cubilin, is a high-affinity apolipoprotein A-I receptor facilitating endocytosis of high-density lipoprotein. Nat Med 5: 656-661.

KOZYRAKI R, FYFE J, VERROUST PJ, JACOBSEN C, DAUTRY-VARSAT A, GBUREK J, WILLNOW TE, CHRISTENSEN EI, MOESTRUP SK (2001) Megalin-dependent cubilin-mediated endocytosis is a major pathway for the apical uptake of transferrin in polarized epithelia. Proc Natl Acad Sci USA 98: 12491-12496.

LAMMERT F, MIQUEL JF (2008) Gallstone disease: from genes to evidencebased therapy. J Hepatol 48 Suppl 1: S124-135.

LARSSON M, HJALM G, SAKWE AM, ENGSTROM A, HOGLUND AS, LARSSON E, ROBINSON RC, SUNDBERG C, RASK L (2003) Selective interaction of megalin with postsynaptic density-95 (PSD-95)-like membrane-associated guanylate kinase (MAGUK) proteins. Biochem J 373: $381-391$.

LEHESTE JR, ROLINSKI B, VORUM H, HILPERT J, NYKJAER A, JACOBSEN C, AUCOUTURIER P, MOSKAUG JO, OTTO A, CHRISTENSEN EI, WILLNOW TE (1999) Megalin knockout mice as an animal model of low molecular weight proteinuria. Am J Pathol 155: 1361-1370

LEHESTE JR, MELSEN F, WELLNER M, JANSEN P, SCHLICHTING U, RENNER-MULLER I, ANDREASSEN TT, WOLF E, BACHMANN S, NYKJAER A WILLNOW TE (2003) Hypocalcemia and osteopathy in mice with kidney-specific megalin gene defect. Faseb J 17: 247-249.

LI GH, ARORA PD, CHEN Y, MCCULLOCH CA, LIU P (2011) Multifunctional roles of gelsolin in health and diseases. Med Res Rev (in press) 
LI Y, LU W, MARZOLO MP, BU G (2001) Differential functions of members of the low density lipoprotein receptor family suggested by their distinct endocytosis rates. J Biol Chem 276: 18000-18006.

LI Y, CONG R, BIEMESDERFER D (2008) The COOH terminus of megalin regulates gene expression in opossum kidney proximal tubule cells. Am J Physiol Cell Physiol 295: C529-537.

LIGHTHOUSE JK, ZHANG L, HSIEH JC, ROSENQUIST T, HOLDENER BC (2010) MESD is essential for apical localization of megalin/LRP2 in the visceral endoderm. Dev Dyn 240: 577-588.

LISI S, BOTTA R, PINCHERA A, COLLINS AB, REFETOFF S, ARVAN P, BU G, GRASSO L, MARSHANSKY V, BECHOUA S, HURTADO-LORENZO A, MARCOCCI C, BROWN D, MCCLUSKEY RT, MARINO M (2006) Defective thyroglobulin storage in LDL receptor-associated proteindeficient mice. Am J Physiol Cell Physiol 290: C1160-1167.

LISI S, BOTTA R, PINCHERA A, COLLINS AB, MARCOCCI C, MARINO M (2008) Kidney abnormalities in low density lipoprotein receptor associated protein knockout mice. J Endocrinol Invest 31: 57-61.

LIU W, YU WR, CARLING T, JUHLIN C, RASTAD J, RIDEFELT P, AKERSTROM G, HELLMAN P (1998) Regulation of gp330/megalin expression by vitamins A and D. Eur J Clin Invest 28: 100-107.

LUNDGREN S, CARLING T, HJALM G, JUHLIN C, RASTAD J, PIHLGREN U, RASK L, AKERSTROM G, HELLMAN P (1997) Tissue distribution of human gp330/megalin, a putative $\mathrm{Ca}(2+)$-sensing protein. J Histochem Cytochem 45: 383-392.

MARINO M, ZHENG G MCCLUSKEY RT (1999) Megalin (gp330) is an endocytic receptor for thyroglobulin on cultured fisher rat thyroid cells. J Biol Chem 274: 12898-12904.

MARINÒ M, ZHENG G, CHIOVATO L, PINCHERA A, BROWN D, ANDREWS D, MCCLUSKEY RT (2000) Role of megalin (gp330) in transcytosis of thyroglobulin by thyroid cells. A novel function in the control of thyroid hormone release. J Biol Chem 275:7125-37.

MARINÓ M, ANDREWS D, BROWN D, MCCLUSKEY RT (2001) Transcytosis of retinol-binding protein across renal proximal tubule cells after megalin (gp 330)-mediated endocytosis. J Am Soc Nephrol 12:637-48.

MARSHANSKY V, AUSIELLO DA, BROWN D (2002) Physiological importance of endosomal acidification: potential role in proximal tubulopathies. Curr Opin Nephrol Hypertens 11: 527-537.

MARWARHA G, DASARI B, PRASANTHI JR, SCHOMMER J, GHRIBI O (2010) Leptin reduces the accumulation of Abeta and phosphorylated tau induced by 27-hydroxycholesterol in rabbit organotypic slices. J Alzheimers Dis 19: 1007-1019.

MARZOLO MP, YUSEFF MI, RETAMAL C, DONOSO M, EZQUER F, FARFAN P, LI Y, BU G (2003) Differential distribution of low-density lipoprotein-receptor-related protein (LRP) and megalin in polarized epithelial cells is determined by their cytoplasmic domains. Traffic 4: 273-288.

MARZOLO MP, BU G (2009) Lipoprotein receptors and cholesterol in APP trafficking and proteolytic processing, implications for Alzheimer's disease. Semin Cell Dev Biol 20: 191-200.

MATTER K, HUNZIKER W, MELLMAN I (1992) Basolateral sorting of LDL receptor in MDCK cells: the cytoplasmic domain contains two tyrosinedependent targeting determinants. Cell 71: 741-753.

MAURER ME, COOPER JA (2005) Endocytosis of megalin by visceral endoderm cells requires the Dab2 adaptor protein. J Cell Sci 118: 53455355.

MCCARTHY RA, BARTH JL, CHINTALAPUDI MR, KNAAK C, ARGRAVES WS (2002) Megalin functions as an endocytic sonic hedgehog receptor. J Biol Chem 277: 25660-25667.

MEZZANO S, DROGUETT A, BURGOS ME, ARDILES LG, FLORES CA, AROS CA, CAORSI I, VIO CP, RUIZ-ORTEGA M, EGIDO J (2003) Reninangiotensin system activation and interstitial inflammation in human diabetic nephropathy. Kidney Int Suppl: S64-70.

MII A, NAKAJIMA T, FUJITA Y, IINO Y, KAMIMURA K, BUJO H, SAITO Y, EMI M, KATAYAMA Y (2007) Genetic association of low-density lipoprotein receptor-related protein 2 (LRP2) with plasma lipid levels. J Atheroscler Thromb 14: 310-316.

MIN BH, KIM BM, LEE SH, KANG SW, BENDAYAN M, PARK IS (2003) Clusterin expression in the early process of pancreas regeneration in the pancreatectomized rat. J Histochem Cytochem 51: 1355-1365.

MIQUEL JF, COVARRUBIAS C, VILLAROEL L, MINGRONE G, GRECO AV, PUGLIELLI L, CARVALLO P, MARSHALL G, DEL PINO G, NERVI F (1998) Genetic epidemiology of cholesterol cholelithiasis among Chilean Hispanics, Amerindians, and Maoris. Gastroenterology 115: 937-946.

MIZUTA K, SAITO A, WATANABE T, NAGURA M, ARAKAWA M, SHIMIZU F, HOSHINO T (1999) Ultrastructural localization of megalin in the rat cochlear duct. Hear Res 129: 83-91.
MOESTRUP SK, NIELSEN S, ANDREASEN P, JØRGENSEN KE, NYKJÆR A, RØIGAARD H, GLIEMANN J, AND CHRISTENSEN EI (1993) Epithelial glycoprotein-330 mediates endocytosis of plasminógeno activatorplasminogen activator inhibitor type-1 complexes. J Biol Chem 268: 16564-16570.

MOESTRUP SK, CUI S, VORUM H, BREGENGÅRD C, BJØRN SE, NORRIS K, GLIEMANN J, CHRISTENSEN EI (1995) Evidence that epithelial glycoprotein $330 /$ megalin mediates uptake of polybasic drugs. J Clin Invest 96: 1404-1413.

MOESTRUP SK, BIRN H, FISCHER PB, PETERSEN CM, VERROUST PJ, SIM RB, CHRISTENSEN EI, NEXØ E (1996) Megalin-mediated endocytosis of transcobalamin-vitamin-B12 complexes suggests a role of the receptor in vitamin-B12 homeostasis. Proc Natl Acad Sci USA 93: $8612-8617$

MOESTRUP SK, SCHOUSBOE I, JACOBSEN C, LEHESTE JR, CHRISTENSEN EI, WILLNOW TE (1998) Beta2-glycoprotein-I (apolipoproteína $\mathrm{H}$ ) and beta2-glycoprotein-I-phospholipid complex harbor a recognition site for the endocytic receptor megalin. J Clin Invest 102: 902-909.

MONACO HL (2000) The transthyretin-retinol-binding protein complex. Biochim Biophys Acta 1482: 65-72.

MORALES CR, IGDOURA SA, WOSU UA, BOMAN J, ARGRAVES WS (1996) Low density lipoprotein receptor-related protein-2 expression in efferent duct and epididymal epithelia: evidence in rats for its in vivo role in endocytosis of apolipoprotein J/clusterin. Biol Reprod 55: 676683.

MORALES CR, ZENG J, EL ALFY M, BARTH JL, CHINTALAPUDI MR MCCARTHY RA, INCARDONA JP, ARGRAVES WS (2006) Epithelial trafficking of Sonic hedgehog by megalin. J Histochem Cytochem 54:1115-27.

MORRIS SM, TALLQUIST MD, ROCK CO, COOPER JA (2002) Dual roles for the Dab2 adaptor protein in embryonic development and kidney transport. Embo J 21: 1555-1564.

NACCACHE SN, HASSON T, HOROWITZ A (2006) Binding of internalized receptors to the PDZ domain of GIPC/synectin recruits myosin VI to endocytic vesicles. Proc Natl Acad Sci U S A 103: 12735-12740.

NAGAI J, CHRISTENSEN EI, MORRIS SM, WILLNOW TE, COOPER JA NIELSEN R (2005) Mutually dependent localization of megalin and Dab2 in the renal proximal tubule. Am J Physiol Renal Physiol 289: F569-576.

NARINS SC, PARK EH, RAMAKRISHNAN R, GARCIA FU, DIVEN JN, BALIN BJ, HAMMOND CJ, SODAM BR, SMITH PR, ABEDIN MZ (2004) Functional characterization of $\mathrm{Na}(+) / \mathrm{H}(+)$ exchangers in primary cultures of prairie dog gallbladder. J Membr Biol 197: 123-134.

NIELSEN R, BIRN H, MOESTRUP SK, NIELSEN M, VERROUST P CHRISTENSEN EI (1998) Characterization of a kidney proximal tubule cell line, LLC-PK1, expressing endocytotic active megalin. J Am Soc Nephrol 9: 1767-1776.

NIELSEN R, COURTOY PJ, JACOBSEN C, DOM G, LIMA WR, JADOT M, WILLNOW TE, DEVUYST O, CHRISTENSEN EI (2007) Endocytosis provides a major alternative pathway for lysosomal biogenesis in kidney proximal tubular cells. Proc Natl Acad Sci U S A 104: 5407-5412.

NIEMEIER A, WILLNOW T, DIEPLINGER H, JACOBSEN C, MEYER N HILPERT J, BEISIEGEL U (1999) Identification of megalin/gp330 as a receptor for lipoprotein(a) in vitro. Arterioscler Thromb Vasc Biol 19: 552-561.

NORDEN AG, LAPSLEY M, IGARASHI T, KELLEHER CL, LEE PJ, MATSUYAMA T, SCHEINMAN SJ, SHIRAGA H, SUNDIN DP, THAKKER RV, UNWIN RJ, VERROUST P, MOESTRUP SK (2002) Urinary megalin deficiency implicates abnormal tubular endocytic function in Fanconi syndrome. J Am Soc Nephrol 13: 125-133.

NUUTINEN T, SUURONEN T, KAUPPINEN A SALMINEN A (2009) Clusterin: a forgotten player in Alzheimer's disease. Brain Res Rev 61: 89-104.

NYKJAER A, DRAGUN D, WALTHER D, VORUM H, JACOBSEN C, HERZ J, MELSEN F, CHRISTENSEN EI, WILLNOW TE (1999) An endocytic pathway essential for renal uptake and activation of the steroid 25-(OH) vitamin D3. Cell 96: 507-515.

NYKJAER A, FYFE JC, KOZYRAKI R, LEHESTE JR, JACOBSEN C, NIELSEN MS, VERROUST PJ, AMINOFF M, DE LA CHAPELLE A, MOESTRUP SK, RAY R, GLIEMANN J, WILLNOW TE, CHRISTENSEN EI (2001) Cubilin dysfunction causes abnormal metabolism of the steroid hormone 25-(OH) vitamin D3. Proc Natl Acad Sci USA 98: 13895-13900.

ODERA K, GOTO S, TAKAHASHI R (2007) Age-related change of endocytic receptors megalin and cubilin in the kidney in rats. Biogerontology 8 : 505-515. 
OLEINIKOV AV, ZHAO J, MAKKER SP (2000) Cytosolic adaptor protein Dab2 is an intracellular ligand of endocytic receptor gp600/megalin. Biochem J 347 Pt 3: 613-621.

OLSON GE, WINFREY VP, HILL KE, BURK RF (2008) Megalin mediates selenoprotein $\mathrm{P}$ uptake by kidney proximal tubule epithelial cells. J Biol Chem 283: 6854-6860.

ORLANDO RA, RADER K, AUTHIER F, YAMAZAKI H, POSNER BI, BERGERON JJ, FARQUHAR MG (1998) Megalin is an endocytic receptor for insulin. J Am Soc Nephrol 9: 1759-1766.

OYAMA Y, TAKEDA T, HAMA H, TANUMA A, IINO N, SATO K, KASEDA R, MA M, YAMAMOTO T, FUJII H, KAZAMA JJ, ODANI S, TERADA Y, MIZUTA K, GEJYO F, SAITO A (2005) Evidence for megalin-mediated proximal tubular uptake of L-FABP, a carrier of potentially nephrotoxic molecules. Lab Invest 85: 522-531.

PALHA JA (2002) Transthyretin as a thyroid hormone carrier: function revisited. Clin Chem Lab Med 40: 1292-1300.

PATRIE KM, DRESCHER AJ, GOYAL M, WIGGINS RC, MARGOLIS B (2001) The membrane-associated guanylate kinase protein MAGI-1 binds megalin and is present in glomerular podocytes. J Am Soc Nephrol 12: 667-677.

PEDERSEN MO, JENSEN R, PEDERSEN DS, SKJOLDING AD, HEMPEL C, MARETTY L, PENKOWA M (2009) Metallothionein-I+II in neuroprotection. Biofactors 35: 315-325.

PETERSEN HH, HILPERT J, MILITZ D, ZANDLER V, JACOBSEN C, ROEBROEK AJ, WILLNOW TE (2003) Functional interaction of megalin with the megalinbinding protein (MegBP), a novel tetratrico peptide repeat-containing adaptor molecule. J Cell Sci 116: 453-461.

PISITKUN T, SHEN RF, KNEPPER MA (2004) Identification and proteomic profiling of exosomes in human urine. Proc Natl Acad Sci U S A 101 13368-13373.

POBER BR, LONGONI M, NOONAN KM (2009) A review of Donnai-Barrow and facio-oculo-acoustico-renal (DB/FOAR) syndrome: clinical features and differential diagnosis. Birth Defects Res A Clin Mol Teratol 85: 76-81.

POLLOCK CAPORONNIK P (2007) Albumin transport and processing by the proximal tubule: physiology and pathophysiology. Curr Opin Nephrol Hypertens 16: 359-364.

RADER K, ORLANDO RA, LOU X, FARQUHAR MG (2000) Characterization of ANKRA, a novel ankyrin repeat protein that interacts with the cytoplasmic domain of megalin. J Am Soc Nephrol 11: 2167-2178.

RANGANATHAN S, KNAAK C, MORALES CR, ARGRAVES WS (1999) Identification of low density lipoprotein receptor-related protein-2/ megalin as an endocytic receptor for seminal vesicle secretory protein II J Biol Chem 274: 5557-5563.

ROWLING MJ, KEMMIS CM, TAFFANY DA, WELSH J (2006) Megalinmediated endocytosis of vitamin D binding protein correlates with 25-hydroxycholecalciferol actions in human mammary cells. J Nutr 136 2754-2759.

RUBERA I, POUJEOL C, BERTIN G, HASSEINE L, COUNILLON L, POUJEOL P, TAUC M (2004) Specific Cre/Lox recombination in the mouse proximal tubule. J Am Soc Nephrol 15: 2050-2056.

RUSSO LM, SANDOVAL RM, MCKEE M, OSICKA TM, COLLINS AB, BROWN D, MOLITORIS BA, COMPER WD (2007) The normal kidney filters nephrotic levels of albumin retrieved by proximal tubule cells: retrieval is disrupted in nephrotic states. Kidney Int 71:504-13.

SAITO A, PIETROMONACO S, LOO AK, FARQUHAR MG (1994) Complete cloning and sequencing of rat gp330/"megalin," a distinctive member of the low density lipoprotein receptor gene family. Proc Natl Acad Sci U S A 91: 9725-9729.

SAITO A, TAKEDA T, HAMA H, OYAMA Y, HOSAKA K, TANUMA A, KASEDA R, UENO M, NISHI S, OGASAWARA S, GONDAIRA F, SUZUKI Y, GEJYO F (2005) Role of megalin, a proximal tubular endocytic receptor, in the pathogenesis of diabetic and metabolic syndrome-related nephropathies: protein metabolic overload hypothesis. Nephrology (Carlton) 10 Suppl: S26-31.

SCHENCK A, GOTO-SILVA L, COLLINET C, RHINN M, GINER A HABERMANN B, BRAND M, ZERIAL M (2008) The endosomal protein Appl1 mediates Akt substrate specificity and cell survival in vertebrate development. Cell 133: 486-497.

SEESTED T, APPA RS, JACOBSEN C, CHRISTENSEN EI (2010) Recombinant Activated Factor VII Is Reabsorbed in Renal Proximal Tubules and Is a Ligand to Megalin and Cubilin. Nephron Exp Nephrol 117: e82-e92.

SEETHARAM B, CHRISTENSEN EI, MOESTRUP SK, HAMMOND TG, VERROUST PJ (1997) Identification of rat yolk sac target protein of teratogenic antibodies, gp280, as intrinsic factor cobalamin receptor. J Clin Invest 99: 2317-2322.

SEKINE T, NOZU K, IYENGAR R, FU XJ, MATSUO M, TANAKA R, IIJIMA K, MATSUI E, HARITA Y, INATOMI J, IGARASHI T (2007) OCRL1 mutations in patients with Dent disease phenotype in Japan. Pediatr Nephrol 22: 975-980.

SEMPLE RK, CHATTERJEE VK O'RAHILLY S (2006) PPAR gamma and human metabolic disease. J Clin Invest 116: 581-589.

SILVIANI V, COLOMBANI V, HEYRIES L, GEROLAMI A, CARTOUZOU G, MARTEAU C (1996) Role of the NHE3 isoform of the $\mathrm{Na}+\mathrm{H}+$ exchanger in sodium absorption by the rabbit gallbladder. Pflugers Arch 432: 791-796

SOUSA MM, NORDEN AG, JACOBSEN C, WILLNOW TE, CHRISTENSEN EI, THAKKER RV, VERROUST PI, MOESTRUP SK, SARAIVA MJ (2000) Evidence for the role of megalin in renal uptake of transthyretin. J Biol Chem 275: 38176-38181.

SPOELGEN R, HAMMES A, ANZENBERGER U, ZECHNER D, ANDERSEN OM, JERCHOW B WILLNOW TE (2005) LRP2/megalin is required for patterning of the ventral telencephalon. Development 132: 405-414.

STEFANSSON S, KOUNNAS MZ, HENKIN J, MALLAMPALLI RK, CHAPPELL DA, STRICKLAND DK, ARGRAVES WS (1995a) Gp330 on type II pneumocytes mediates endocytosis leading to degradation of pro-urokinase, plasminogen activator inhibitor-1 and urokinaseplasminogen activator inhibitor-1 complex. J Cell Sci 108: 2361-2368.

STEFANSSON S, CHAPPELL DA, ARGRAVES KM, STRICKLAND DK, ARGRAVES WS (1995b) Glycoprotein 330/low density lipoproteína receptor-related protein-2 mediates endocytosis of low density lipoproteins via interaction with apolipoprotein B100. J Biol Chem 270: 19417-19421.

TAURIS J, CHRISTENSEN EI, NYKJAER A, JACOBSEN C, PETERSEN CM, OVESEN T (2009) Cubilin and megalin co-localize in the neonatal inner ear. Audiol Neurootol 14:267-278

TOJO A, ONOZATO ML, KURIHARA H, SAKAI T, GOTO A, FUJITA T (2003) Angiotensin II blockade restores albumin reabsorption in the proximal tubules of diabetic rats. Hypertens Res 26: 413-419.

TSAROUCHA AK, CHATZAKI E, LAMBROPOULOU M, DESPOUDI K, LAFTSIDIS P, CHARSOU C, POLYCHRONIDIS A, PAPADOPOULOS N, SIMOPOULOS CE (2008) Megalin and cubilin in the human gallbladder epithelium. Clin Exp Med 8: 165-170.

UTSCH B, BOKENKAMP A, BENZ MR, BESBAS N, DOTSCH J, FRANKE I, FRUND S, GOK F, HOPPE B, KARLE S, KUWERTZ-BROKING E, LAUBE G, NEB M, NUUTINEN M, OZALTIN F, RASCHER W, RING T, TASIC V, VAN WIJK JA, LUDWIG M (2006) Novel OCRL1 mutations in patients with the phenotype of Dent disease. Am J Kidney Dis 48: 942 e941-914.

VAN DRIEL M, KOEDAM M, BUURMAN CJ, HEWISON M, CHIBA H, UITTERLINDEN AG, POLS HA, VAN LEEUWEN JP (2006) Evidence for auto/paracrine actions of vitamin D in bone: 1alpha-hydroxylase expression and activity in human bone cells. Faseb J 20: 2417-2419.

VAN KERKHOF P, LEE J, MCCORMICK L, TETRAULT E, LU W, SCHOENFISH M, OORSCHOT V, STROUS GJ, KLUMPERMAN J, BU G (2005) Sorting nexin 17 facilitates LRP recycling in the early endosome. Embo J 24: 2851-2861.

VARGAS T, ANTEQUERA D, UGALDE C, SPUCH C, CARRO E (2010a) Gelsolin restores A beta-induced alterations in choroid plexus epithelium. J Biomed Biotechnol 2010: 805405.

VARGAS T, BULLIDO MJ, MARTINEZ-GARCIA A, ANTEQUERA D, CLARIMON J, ROSICH-ESTRAGO M, MARTIN-REQUERO A MATEO I, RODRIGUEZ-RODRIGUEZ E, VILELLA-CUADRADA E, FRANK A, LLEO A, MOLINA-PORCEL L, BLESA R, COMBARROS O, GOMEZ-ISLA T, BERMEJO-PAREJA F, VALDIVIESO F, CARRO E (2010b) A megalin polymorphism associated with promoter activity and Alzheimer's disease risk. Am J Med Genet B Neuropsychiatr Genet 153B: 895-902.

VIO CP, JEANNERET VA (2003) Local induction of angiotensin-converting enzyme in the kidney as a mechanism of progressive renal diseases. Kidney Int Suppl: S57-63.

WATANABE T (2004) Megalin and proximal renal tubular dysfunction in Dent disease. Pediatr Nephrol 19: 1305; author reply 1306.

WHITE F, NICOLL JA, HORSBURGH K (2001) Alterations in ApoE and ApoJ in relation to degeneration and regeneration in a mouse model of entorhinal cortex lesion. Exp Neurol 169: 307-318.

WICHER G, LARSSON M, RASK LALDSKOGIUS H (2005) Low-density lipoprotein receptor-related protein (LRP)-2/megalin is transiently expressed in a subpopulation of neural progenitors in the embryonic mouse spinal cord. J Comp Neurol 492: 123-131.

WICHER G, LARSSON M, FEX SVENNINGSEN A, GYLLENCREUTZ E, RASK L, ALDSKOGIUS H (2006) Low density lipoprotein receptorrelated protein-2/megalin is expressed in oligodendrocytes in the mouse spinal cord white matter. J Neurosci Res 83: 864-873. 
WILLNOW TE, GOLDSTEIN JL, ORTH K, BROWN MS, HERZ J (1992) Low density lipoprotein receptor-related protein and gp330 bind similar ligands, including plasminogen activator-inhibitor complexes and lactoferrin, an inhibitor of chylomicron remnant clearance. J Biol Chem 267: 26172-26180.

WILLNOW TE, HILPERT J, ARMSTRONG SA, ROHLMANN A, HAMMER RE, BURNS DK, HERZ J (1996) Defective forebrain development in mice lacking gp330/megalin. Proc Natl Acad Sci U S A 93: 8460-8464.

WILLNOW TE (1999) The low-density lipoprotein receptor gene family: multiple roles in lipid metabolism. J Mol Med 77: 306-315.

WOLF G, ZIYADEH FN (2006) Leptin and renal fibrosis. Contrib Nephrol 151: 175-183.

WOLFF NA, ABOUHAMED M, VERROUST PJ, THEVENOD F (2006) Megalin-dependent internalization of cadmium-metallothionein and cytotoxicity in cultured renal proximal tubule cells. J Pharmacol Exp Ther 318: 782-791.

WOLFF NA, LEE WK, ABOUHAMED M, THEVENOD F (2008) Role of ARF6 in internalization of metal-binding proteins, metallothionein and transferrin, and cadmium-metallothionein toxicity in kidney proximal tubule cells. Toxicol Appl Pharmacol 230: 78-85.

YANG DH, CAI KQ, ROLAND IH, SMITH ER XU XX (2007) Disabled-2 is an epithelial surface positioning gene. J Biol Chem 282: 13114-13122.

YUSEFF MI, FARFAN P, BU G, MARZOLO MP (2007) A cytoplasmic PPPSP motif determines megalin's phosphorylation and regulates receptor's recycling and surface expression. Traffic 8: 1215-1230.

ZENG X, TAMAI K, DOBLE B, LI S, HUANG H, HABAS R, OKAMURA H, WOODGETT J, HE X (2005) A dual-kinase mechanism for Wnt coreceptor phosphorylation and activation. Nature 438: 873-877.

ZHANG R, LIAO J, MORSE S, DONELON S, REISIN E (2005) Kidney disease and the metabolic syndrome. Am J Med Sci 330: 319-325.
ZHANG Y, GUAN Y (2005) PPAR-gamma agonists and diabetic nephropathy. Curr Diab Rep 5: 470-475.

ZHAO J, OLEINIKOV AV, OLEINIKOVA I, MAKKER SP (2001) Functional characterization of rat gp600/megalin promoter: combination of proximal Sp1 site and JCV repeat is important in rat gp600/megalin promoter activation. Gene 265: 123-131.

ZHAO S, GUAN KL (2008) Substrate selectivity APPLies to Akt. Cell 133: 399-400.

ZHENG G, MARINO M, ZHAO J, MCCLUSKEY RT (1998) Megalin (gp330): a putative endocytic receptor for thyroglobulin (Tg). Endocrinology 139: 1462-1465.

ZHOU H, CHERUVANKY A, HU X, MATSUMOTO T, HIRAMATSU N, CHO ME, BERGER A, LEELAHAVANICHKUL A, DOI K, CHAWLA LS, ILLEI GG, KOPP JB, BALOW JE, AUSTIN HA 3rd, YUEN PS, STAR RA (2008) Urinary exosomal transcription factors, a new class of biomarkers for renal disease. Kidney Int 74: 613-621.

ZLOKOVIC BV (1996) Cerebrovascular transport of Alzheimer's amyloid beta and apolipoproteins $\mathrm{J}$ and $\mathrm{E}$ : possible anti-amyloidogenic role of the blood-brain barrier. Life Sci 59: 1483-1497.

ZLOKOVIC BV, MARTEL CL, MATSUBARA E, MCCOMB JG, ZHENG G, MCCLUSKEY RT, FRANGIONE B, GHISO J (1996) Glycoprotein 330/ megalin: probable role in receptor-mediated transport of apolipoprotein $\mathrm{J}$ alone and in a complex with Alzheimer disease amyloid beta at the blood-brain and blood-cerebrospinal fluid barriers. Proc Natl Acad Sci U S A 93: 4229-4234.

ZOU Z, CHUNG B, NGUYEN T, MENTONE S, THOMSON B, BIEMESDERFER D (2004) Linking receptor-mediated endocytosis and cell signaling: evidence for regulated intramembrane proteolysis of megalin in proximal tubule. J Biol Chem 279: 34302-34310. 
